\title{
The Cross-Talk Between Sphingolipids and Insulin-Like Growth Factor Signaling: Significance for Aging and Neurodegeneration
}

\author{
Henryk Jęśko ${ }^{1} \cdot$ Adam Stępień $^{2} \cdot$ Walter J. Lukiw ${ }^{3} \cdot$ Robert P. Strosznajder $^{4}$ (D)
}

Received: 31 May 2018 / Accepted: 25 July 2018 / Published online: 23 August 2018

(C) The Author(s) 2018

\begin{abstract}
Bioactive sphingolipids: sphingosine, sphingosine-1-phosphate (S1P), ceramide, and ceramide-1-phosphate (C1P) are increasingly implicated in cell survival, proliferation, differentiation, and in multiple aspects of stress response in the nervous system. The opposite roles of closely related sphingolipid species in cell survival/death signaling is reflected in the concept of tightly controlled sphingolipid rheostat. Aging has a complex influence on sphingolipid metabolism, disturbing signaling pathways and the properties of lipid membranes. A metabolic signature of stress resistance-associated sphingolipids correlates with longevity in humans. Moreover, accumulating evidence suggests extensive links between sphingolipid signaling and the insulin-like growth factor I (IGF-I)-Akt-mTOR pathway (IIS), which is involved in the modulation of aging process and longevity. IIS integrates a wide array of metabolic signals, cross-talks with $\mathrm{p} 53$, nuclear factor $\mathrm{\kappa B}(\mathrm{NF}-\mathrm{kB})$, or reactive oxygen species (ROS) and influences gene expression to shape the cellular metabolic profile and stress resistance. The multiple connections between sphingolipids and IIS signaling suggest possible engagement of these compounds in the aging process itself, which creates a vulnerable background for the majority of neurodegenerative disorders.
\end{abstract}

Keywords Ceramide $\cdot$ Sphingosine-1-phosphate $\cdot$ Aging $\cdot$ Neurodegeneration $\cdot$ Insulin-like growth factor $\cdot$ Mitochondria

\section{Sphingolipid Biosynthesis and Signaling}

Bioactive sphingolipids: ceramide, ceramide-1-phosphate (C1P), and sphingosine-1-phosphate (S1P) play numerous roles in nervous system development and in the acquisition of the mature neuronal phenotype, and as such are key regulators of cell proliferation, differentiation, survival, and the stress response $[1,2]$. Their opposite influence on cell survival/death signaling is

Robert P. Strosznajder

rstrosznajder@imdik.pan.pl

1 Department of Cellular Signalling, Mossakowski Medical Research Centre, Polish Academy of Sciences, Warsaw, Pawińskiego 5, 02-106, Poland

2 Central Clinical Hospital of the Ministry of National Defense, Department of Neurology, Military Institute of Medicine, Warsaw, Szaserów 128, 04-141, Poland

3 LSU Neuroscience Center and Departments of Neurology and Ophthalmology, Louisiana State University School of Medicine, New Orleans, USA

4 Laboratory of Preclinical Research and Environmental Agents, Department of Neurosurgery, Mossakowski Medical Research Centre, Polish Academy of Sciences, Warsaw, Pawińskiego 5, 02-106, Poland reflected in the concept of highly regulated sphingolipid rheostat and justifies their vast importance in aging and neurodegeneration $[3,4]$. Mutations or loss of sphingolipid metabolism enzymes frequently lead to neuronal dysfunction and degeneration or are embryonically lethal [5-7]. Sphingolipids can be secreted into extracellular medium and bind cell surface receptors. They also interact with intracellular signaling pathways [8], bind transmembrane domains of signaling proteins within the lipid bilayer [9], or even create membrane pores in mitochondria [10]. Sphingolipids can also modify the operating environment of target proteins through their structural roles as membrane components, potentially facilitating signal amplification and/or the integration of multiple biological signals.

\section{The Three Pathways of Ceramide Biosynthesis}

Ceramide has mostly attracted attention due to its roles not only in cell death and senescence but also in differentiation, maintenance of axonal/synaptic structure, and its links with immunological activation [11, 12]. Ceramide also plays important structural roles in organellar and cellular membranes and their microdomains, including lipid rafts, modulating membrane fluidity, and the biophysical mechanisms of protein anchoring $[13,14]$. 
As a signaling molecule, ceramide is known to bind specific motifs in protein kinases, phosphatases, calcium-binding proteins, DNA repair and heat shock proteins $[12,15,16]$. Ceramide-induced processes such as axonal degeneration/ apoptosis comprise both caspase-mediated and caspaseindependent pathways involving mitochondrial reactive oxygen species (ROS), p53, Akt, glycogen synthase kinase $3 \beta$ (GSK$3 \beta$, which phosphorylates tau), or the transcription factor activator protein 1 (AP-1) [11, 17-19]. However, some ceramide synthase (CerS) isoforms and ceramide species may have opposite effect on apoptotic and autophagic cell death [20, 21]. Ceramides' significance for aging and neurodegeneration is also linked to their role in the mitochondrial quality assurance pathways.

Three main pathways of ceramide generation have been described: de novo biosynthesis from serine and palmitoylcoenzyme A, the sphingomyelinase pathway, and the salvage pathway that re-creates ceramide from sphingosine (Fig. 1):

- Serine palmitoyltransferase (SPT) catalyzes the first, ratelimiting step of sphingolipid biosynthesis. SPT product is then converted into sphinganine (dihydrosphingosine) which is used by CerS to generate dihydroceramide [22], which recently emerges as a signaling molecule on its own $[23,24]$. Dihydroceramide is then converted to ceramide by dihydroceramide desaturase.

- Ceramides can give rise to sphingomyelin [25] produced by sphingomyelin synthase (SGMS or SMS). The opposite reaction catalyzed by sphingomyelinases (SMases or SMPDs), termed the sphingomyelinase pathway is a major ceramide source [26].

- Ceramide can be further converted by ceramidases into sphingosine [27] which modulates the cell death machinery and nitric oxide (NO) signaling [28, 29]. Thanks to their relatively broad substrate specificity, ceramide synthases (there are CerS1 to 6, also named longevity assurance gene homologs Lass1 to 6) can re-synthesize ceramide from sphingosine (the salvage pathway). The presence of six tightly regulated and interdependent ceramide synthases plus their splice variants assures the necessary variation in synthesized ceramides [30]. CerSs are known to undergo phosphorylation, acetylation, $\mathrm{N}$-glycosylation, and ubiquitination, implying tight (but still poorly understood) regulation $[30,31]$.

\section{Sphingosine-1-Phosphate and Ceramide-1-Phosphate}

Both sphingosine and ceramide can be phosphorylated into their respective 1-phosphates (S1P and C1P). For years, the roles of bioactive sphingolipids have been interpreted using the sphingolipid rheostat model which implies survival- de novo

pathway

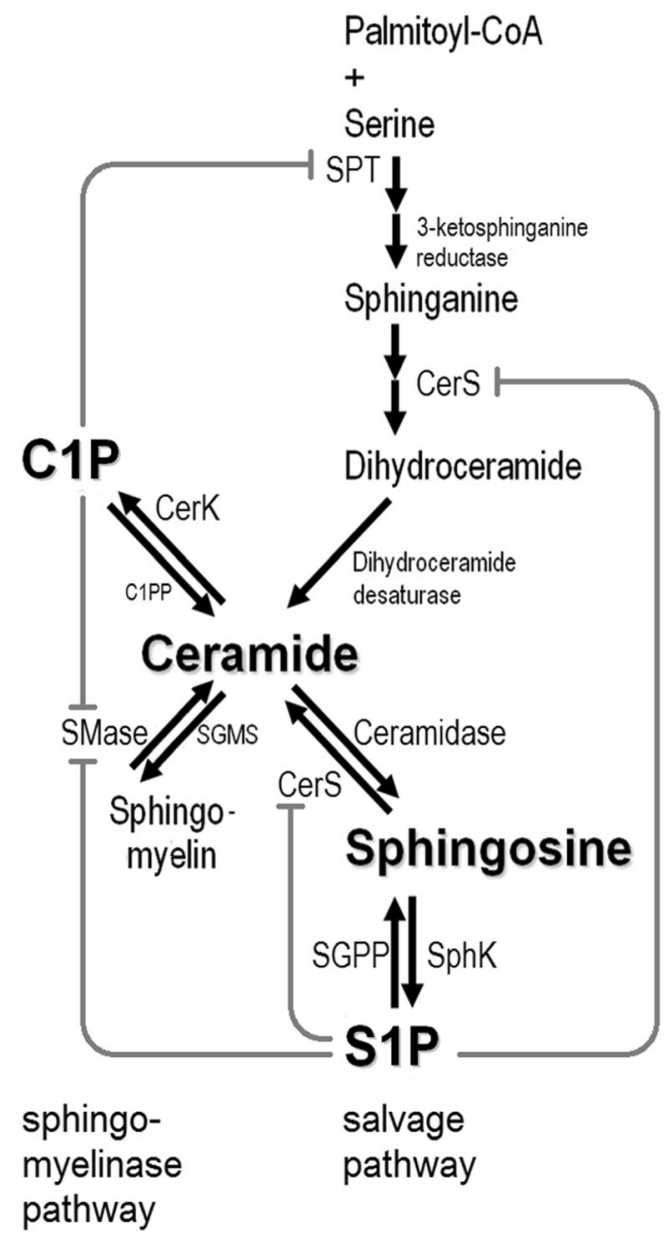

Fig. 1 Sphingolipid metabolism and the three pathways of ceramide biosynthesis. The scheme shows only selected reactions and enzymes, plus their feedback regulation by $\mathrm{S} 1 \mathrm{P}$ and $\mathrm{C} 1 \mathrm{P}$. C1P, ceramide-1phosphate; C1PP, C1P phosphatase; CerK, ceramide kinase; CerS, (dihydro)ceramide synthase; S1P, sphingosine-1-phosphate; SGMS, sphingomyelin synthase; SGPP, S1P phosphatase; SMase, sphingomyelinase; SPT, serine palmitoyltrasnferase

promoting activities of sphingolipid phosphates in contrast with the pro-apoptotic ceramide. Although the model still seems to correctly describe the prevailing significance of each compound class, the roles are no longer clear cut.

The pro-survival activity of S1P highlights its role in brain physiology and the potential significance as therapeutic target in neurodegenerative disorders [32-34]. S1P mediates the actions of numerous anti-apoptotic compounds such as nerve growth factor or glial-derived neurotrophic factor [4]. Largely through phosphoinositide 3-kinase (PI3K)-Akt, the sphingosine kinase (SphK) signaling targets pro-apoptotic proteins Bad (Bcl-2-associated agonist of cell death) and GSK-3 $\beta$ [17] and nuclear transcription factors including known regulators of apoptosis. The latter include forkhead box, sub-group $\mathrm{O}$ transcription factors (FOXO) [35], NF-kB [8, 36], and AP-1 


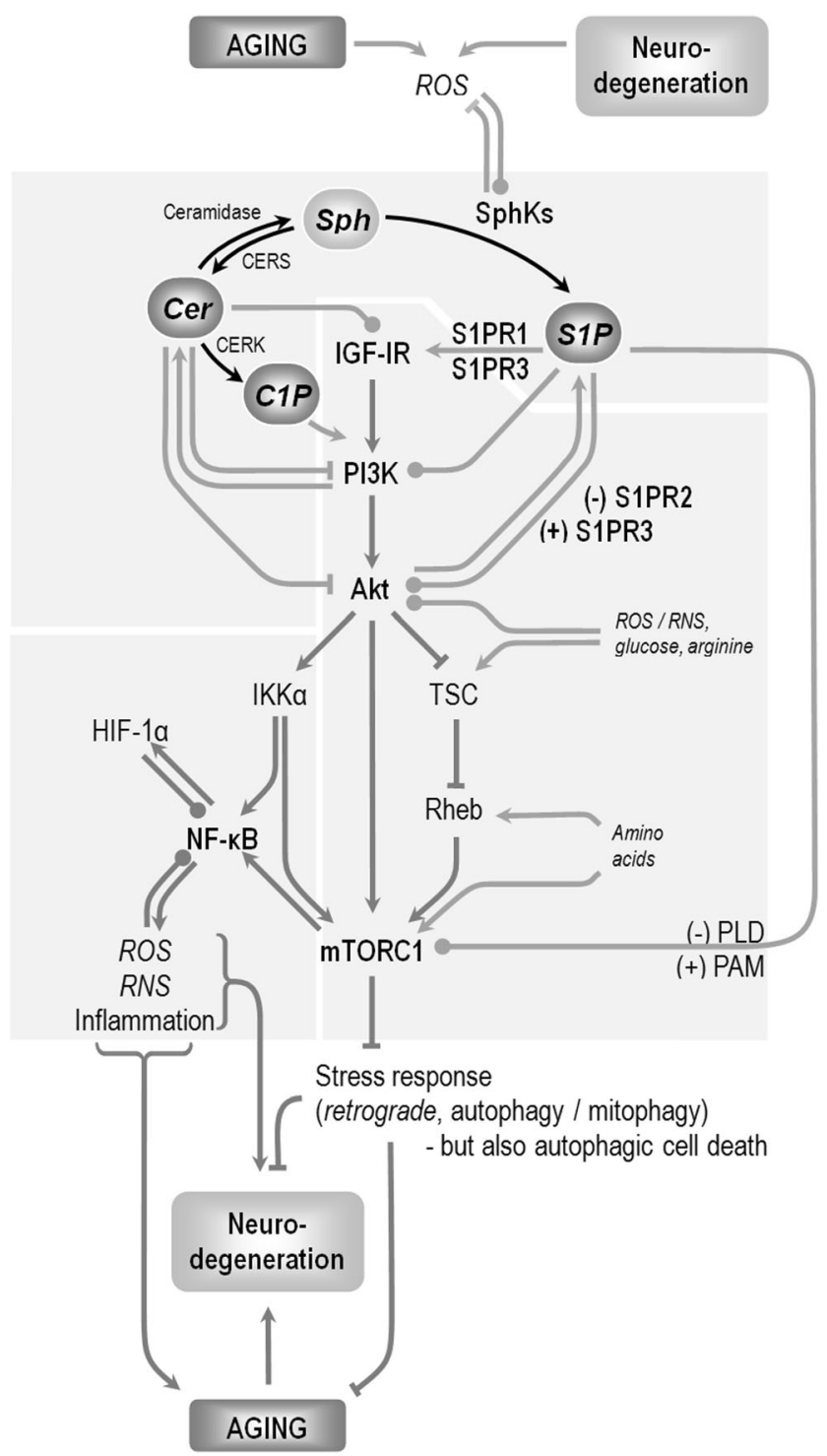

which is also engaged in the network of mutual co-regulation between sphingolipid-related genes [37-39]. However, prolonged accumulation of S1P (produced by SphK2) can cause endoplasmic reticulum stress and cell death [4, 40]. Some of S1P's mediators, such as AP-1 [41], extracellular signal-regulated kinases (ERK) [42, 43], or NF-KB [44, 45] can also lead to various neurological outcomes [40-45].

S1P production by SphKs undergoes extensive regulation by numerous inputs including growth factors, inflammatory cytokines, or calcium ions [46, 47]. S1P is dephosphorylated back to sphingosine by phosphatases SGPP1 and SGPP2. S1P can also be irreversibly hydrolyzed by the SGPL lyase [48] into hexadecenal (which has its own signaling functions [49]) and ethanolamine phosphate.

S1P can both play the role of an intracellular second messenger, or act on multiple cell types through surface S1P receptors in auto-/paracrine fashion. S1P can be transported to more distant targets in the cerebrospinal fluid or in the
Fig. 2 Modulation of the PI3K-Akt-mTOR signaling by bioactive sphingolipids. Bi-directional interactions with cellular stress, aging, and neurodegeneration. Selected enzymes of sphingolipid metabolism with known significance for the modification of the aging process are shown. Akt, protein kinase B; C1P, ceramide-1-phosphate; Cer, ceramide; CerK, ceramide kinase; CerS (LASS), ceramide synthase; HIF- $1 \alpha$, hypoxiainducible factor- $1 \alpha$; IGF-IR, insulin-like growth factor receptor; IKK, inhibitor of NF- $\mathrm{kB}$ kinase; mTORC1, mammalian (or: mechanistic) target of rapamycin complex 1 ; NF- $\mathrm{kB}$, nuclear factor $\kappa \mathrm{B}$; PAM, protein associated with Myc; PI3K, class I phosphoinositide 3-kinase; PLD, phospholipase D; Rheb, Ras homolog enriched in the brain; RNS, reactive nitrogen species; ROS, reactive oxygen species; S1P, sphingosine-1-phosphate; S1PR, cell surface G protein-binding S1P receptors; Sph, sphingosine; SphK, sphingosine kinase(s); TSC, tuberous sclerosis protein. $\longrightarrow$ symbols denote varied/ambiguous influence (e.g., depending on the cell model used, the presence of RNS has been found to either activate or inhibit IKK $\beta$ ). The scheme skips additional interactions, such as the links between ceramide itself and stress, the inhibitory phosphorylation of TSC 1 by IKK $\beta$, or feedback influences of mTOR on PI3K-Akt. Sphingolipids can modulate mTOR in multiple ways, potentially allowing cell type/subcellular compartmentspecific functioning of the S1P-mTOR branch. mTORC1 activation occurs on the surface of various organellar membranes, and details of the pathway may be different depending on the cell region. According to $[3,52]$, modified

bloodstream $[1,11,12,50]$. The cell surface, low-nanomolar affinity S1P receptors of the Edg family (termed S1P1 to 5) bind $\mathrm{G}_{\mathrm{q}}, \mathrm{G}_{\mathrm{i}}, \mathrm{G}_{12 / 13}$, and Rho proteins which relay signals to PI3K, protein kinase C (PKC), phospholipases, or cyclic adenosine monophosphate (cAMP) [51] (Fig. 2). S1PRs influence neuronal viability, excitability, and neurite extension/ retraction [53]. S1PRs also modulate the interactions between neurons and microglia and possibly decide about the outcome (restorative vs. neurotoxic) of astroglial immune activation $[53,54]$. The nervous system is enriched in S1PR proteins, especially S1PR1 (whose expression changes with age), S1PR3, and S1PR5. S1PR2 undergoes low-level, genderspecific brain expression [55]. Neurons, astrocytes, and microglia express S1PR1-3 and S1PR5, while oligodendrocytes and their precursors possess S1P1, S1P3, and S1P5 $[53,56]$. Cell surface receptor-mediated S1P signaling includes feedback effects such as reduction of SphK1 expression in response to S1PR2 activation or ligand-induced receptor internalization (this phenomenon is exploited in the therapy of relapsing remitting multiple sclerosis that employs fingolimod, a S1P receptor modulator [53]), [57, 58].

The second messenger function requires S1P generation to occur in various intracellular compartments including nucleus. Although nuclear pores should allow exchange of sphingolipids with the cytoplasm, their nuclear pools show large degree of autonomy, and sphingolipid metabolism enzymes exist in the nucleus (including ceramide and sphingosine kinases, sphingomyelin synthase, and sphingomyelinase) [51]. SPHK2 has been found to participate in repressor complexes with histone deacetylases (HDAC1 and 2), while S1P can bind both HDAC proteins and inhibit their deacetylase 
activity [59]. These varied mechanisms of nuclear signaling appear to be important for inflammaging and neurodegenerative conditions (Alzheimer's disease (AD)), along with the above mentioned sphingolipid-mediated modulation of transcription factors [49, 60, 61].

$\mathrm{C} 1 \mathrm{P}$ stimulates cellular proliferation and survival and antagonizes ceramide (Fig. 2) [62-67]. However, C1P can be cytotoxic at high concentrations [68], and it can stimulate ROS-based signaling and lead to induction of the NO synthase iNOS $[69,70]$. Surprisingly, at least in some cases, Aktand NF-KB-dependent iNOS stimulation might actually mediate the pro-survival effects of C1P [70]. C1P employs several mechanisms to exert its influence on downstream mediators. While it can bind its intracellular target enzymes directly $[71,72]$, it can also cross the plasma membrane $[68,73]$ and Granado et al. suggested the existence of a specific, low affinity plasmalemmal C1P receptor that signals through $G_{i}$ protein to the known mediators of C1P activities: PI3K/Akt, NF- $\mathrm{KB}$, and mitogen-activated protein kinase kinase (MEK)/ ERK [74].

\section{Bioactive Sphingolipids in Aging}

Numerous alterations in sphingolipid metabolism are observed during human and rodent aging (Table 1). A characteristic set of lipids possibly linked to stress resistance has been found to correlate with longevity [80]. The known association of sphingolipids and IIS with immune signaling also hints at their potential significance for inflamm-aging, which is important for the pathological, real-life trajectories of homoeostasis deterioration in old age $[93,94]$. In humans, the hippocampal sphingolipid balance tends to change with age towards ceramide and sphingosine; this likely contributes to the worsening of the conditions for neuronal survival [83].

The knowledge of the mechanisms of sphingolipid involvement in human aging/longevity is highly incomplete. Most work has been done on yeast and nematode models, and results draw attention to the extensive cross-talk between sphingolipids and IIS.

\section{Ceramides in the Stress Response and Cellular Senescence}

Evidence from yeast studies points to the links between ceramide metabolism and aging [95, 96]. A CerS subunit gene has been identified as longevity-assurance gene 1 (LAG1) in the yeast replicative senescence model [25]. The effects of its manipulation on the lifespan are complex, while its mild overexpression increases the replicative potential, higher levels lead to its reduction [97]. However, in Drosophila ablation of an alkaline ceramidase can improve lifespan and oxidative stress resistance [98]. Results obtained in Caenorhabditis elegans suggest that age-related changes in relative concentrations of ceramide subspecies are absent in the long-living calorie-restricted adults or dauer larvae, pointing to the potential significance of fine-tuning of ceramide metabolism for the aging process [99]. Inhibition or knockdown of acid sphingomyelinase, serine palmitoyltransferase, or glucosylceramide synthase in $C$. elegans lead to longer lifespan; the effects are partially mediated via IIS signaling $[99,100]$.

The known links between ceramides and stress, which is one of the driving forces of aging [101-104], are extensive also in mammalian tissue.

- Ceramides seem to respond to the inefficiencies in the ROS control. Ceramide content is elevated early in the $\mathrm{Cu} / \mathrm{Zn}$ SOD (superoxide dismutase) mouse mutants and in human amyotrophic lateral sclerosis patients with this mutation [105]. It is suggested that physiological glutathione (GSH) levels inhibit neutral sphingomyelinase (nSMase), and the enzyme's activity only rises when glutathione is depleted by, e.g., oxidative or alkylating agents or cell senescence [106].

- Ceramide levels can also be enhanced by the oxidative stress sensor $\mathrm{p} 53$, a protein engaged in the regulation of aging/senescence [107].

- Ceramide and the enzymes of its metabolism are linked bi-directionally with AP-1, a redox-sensitive transcription factor engaged in cellular senescence, responses to oxidative stress and DNA damage [108]. Cytoprotective effects of serum growth factors include activation of the neutral ceramidase gene via AP-1 [39]. However, also CERS4 and 5 genes are activated by AP-1. Thus, the complex regulation of AP-1 may enable it to stimulate or suppress ceramide levels [38]. In turn, ceramide inhibits AP-1, creating a feedback loop ensuring tight control over its own concentration $[19,109]$.

\section{Sphingosine-1-Phosphate, Stress Signaling, and Senescence}

Despite extensive links between S1P and proliferation control, the significance of S1P for the modulation of cellular senescence is poorly characterized. Inhibition of SphK1 leads to p53- and p21-dependent senescence in a human cell line [110]. SphK1 reacts to oxidative stress in a apparently bimodal fashion. While moderate stress activates it, high ROS production can lead to its inhibition and/or degradation. This phenomenon probably reflects a switch that occurs in excessively damaged cells, which directs the resources away from building stress resistance, and instead activates apoptosis [3]. This switch reflects the behavior of $\mathrm{p} 53$, and $\mathrm{p} 53$ is indeed 
Table 1 Changes of sphingolipid metabolism/signaling in aging and $\mathrm{AD}$

\begin{tabular}{|c|c|}
\hline Aging & $\mathrm{AD}$ \\
\hline $\begin{array}{l}\uparrow \text { membrane neutral SMase activity. } \\
\downarrow \text { cytosolic neutral SMase activity [75] }\end{array}$ & $\begin{array}{l}\uparrow \text { human AD brain mRNA levels: CERS1, CERS2, SGPL1, SPTLC2, } \\
\text { acid SMase [76, 77], although CerS2 activity is reduced [78]. } \\
\downarrow \text { human AD brain mRNAs: ASAH1, CERK, and CERS6 [76]. } \\
\downarrow \text { human SphK1 and SphK2 activity in the hippocampus [79]; } \\
\text { specific SphK2 activity increased in AD frontal cortex [78] }\end{array}$ \\
\hline $\begin{array}{l}\text { A "signature"'set of lipids associate } \\
\text { with human longevity [80] }\end{array}$ & $\begin{array}{l}\text { Human brain sphingomyelin and hydroxysphingomyelin species } \\
\text { correlate with the future AD onset in asymptomatic/healthy subjects, } \\
\text { and with progression at the pre-symptomatic/prodromal stages [81]. } \\
\text { Serum levels of selected sphingomyelins correlate with progression } \\
\text { from MCI to AD [82] }\end{array}$ \\
\hline $\begin{array}{l}\downarrow \mathrm{S} 1 \mathrm{P} / \text { sphingosine ratio in human aging } \\
\text { hippocampus (only in females) [83] }\end{array}$ & $\begin{array}{l}\downarrow \text { S1P levels in human AD brain hippocampus and inferior temporal cortex; } \\
\text { hippocampal changes correlate with Braak stage of neuropathology [79] }\end{array}$ \\
\hline $\begin{array}{l}\uparrow \text { human hippocampal ceramide [83]. } \\
\uparrow \text { ceramide/sphingomyelin ratio in the rat serum, } \\
\text { liver, heart, and skeletal muscle [84]. } \\
\uparrow \text { various human ceramide species [85]. } \\
\uparrow \text { ceramide/sphingomyelin ratio in the rat serum, } \\
\text { liver, heart, and skeletal muscle [84]. } \\
\text { Contradictory changes of various ceramides } \\
\text { in centenarians [80] }\end{array}$ & $\begin{array}{l}\uparrow \text { human brain ceramide levels-including the earliest clinically recognizable } \\
\text { AD stage (MCI) }[77,86-88]\end{array}$ \\
\hline $\begin{array}{l}\uparrow \text { human hippocampal sphingomyelin level [83]. } \\
\uparrow \text { sphingomyelins in the mouse hippocampus [89] } \\
\text { and rat amygdala [90]. } \\
\uparrow \text { human blood plasma sphingomyelins [91] }\end{array}$ & Incoherent results on sphingomyelin changes in AD patient serum [92] \\
\hline
\end{tabular}

The table includes only observations in naturally aging humans and rodents and from human AD cases

$A S A H 1$, an acid ceramidase; $C 1 P$, ceramide-1-phosphate; $C 1 P P$, C1P phosphatase; CerK, ceramide kinase; CerS, (dihydro)ceramide synthase; $M C I$, mild cognitive impairment; S1P, sphingosine-1-phosphate; SGMS, sphingomyelin synthase; SGPL, S1P lyase; SGPP, S1P phosphatase; SMase, sphingomyelinase; $S P T$, serine palmitoyltrasnferase; SPTLC, SPT long-chain base subunit 1

upstream of SphK1 (p53 can activate SphK1 degradation by cysteine proteases) $[111,112]$. In turn, SphK1 seems to suppress ROS production [113], and this phenomenon significantly contributes to the known protective effects of ischemic preconditioning, as shown in the heart [114]. The dualistic reaction of SphK1 to oxidative stress has led to a proposal that it could be engaged in the longevity control, probably via its links with ROS and their sensor hypoxia-inducible factor (HIF-1) [3].

The ability of sphingosine kinases to modulate ceramide metabolism (Fig. 1) may have additional impact upon stress signaling and resistance. SphK1 can influence ceramide synthesis on the de novo and salvage pathways by changing CerS1 intracellular localization and probably SPT and CerS activities [115-117]. In turn, SphK2 overexpression can lead to increased ceramide synthesis [117].

S1P produced by SphK2 binds human telomerase catalytic subunit in human and mouse cells, preventing its ubiquitindependent degradation. Disruption of telomerase-S1P binding leads to telomere erosion and acquisition of the senescent phenotype [118]. In turn, up-regulated S1PR2 expression occurs in senescent cells of various types, and S1PR2 activity has been demonstrated to support cellular senescence $[57,119,120]$.

The expression and activity of the transcription factor AP-1 is also dependent on S1PR1/S1PR3 signaling [121], suggesting further roles for S1P in cellular senescence. A positive regulatory loop appears to exist between SphK1 and AP-1, as the SPHK1 gene contains AP-1 binding elements, and its expression is dependent on c-Fos and c-Jun [37].

\section{Bioactive Sphingolipids and the Insulin-Like Signaling Pathway of Aging Modulation}

Perhaps the most promising (though still incompletely characterized) mechanism of metabolic and stress control by sphingolipids is mediated by the versatile IIS pathway. IIS, a highly inter-connected metabolic regulatory system, is implicated in stress resistance/aging modulation throughout the spectrum of organisms from nematodes to vertebrates [122, 123]. Interestingly, many roles of S1P appear to be largely analogous to those of IIS, including not only the welldocumented cell survival/death signaling but also the engagement in organism's energy homoeostasis [124]. 
IGF-I receptor (IGF-IR) signaling is tightly associated with lipid rafts, which might sensitize it to the structural influence of sphingolipids on cell membrane microdomain properties [125]. Accumulating evidence also suggests links between signaling activities of sphingolipids and the wide spectrum of IIS activities (Fig. 2). Increased SphK1 expression and S1PR1/S1PR3 signaling are engaged in the IGF-IR activation [126]. C2 ceramide alters the expression of several IIS genes in a tissue-specific manner, including reduced IGF-IR and insulin receptor substrate IRS-1 or elevated IRS-2 and IGFbinding protein 1 (IGFBP1) in liver cells [127, 128]. IGFBPs are carrier proteins that not only regulate IGF-I bioavailability but can also have IGF-independent modulatory influence on cell survival [129]. nSMases have been shown to modulate the expression of IGFBP1 via FOXO1 [128, 130]. In the nematode-aging model, a number of ceramide-synthesizing enzymes signal largely through IIS, limiting the lifespan as mentioned previously [99, 100]. Worm sphk-1 mutants live shorter and are more susceptible to heat stress [131].

Phosphatidylinositol 3-kinase (PI3K) receives signals from plasma membrane receptors that bind growth factors (IGFIR), hormones (insulin), and from chemokines [132].

- S1P synthesis by both SphKs has been found to be activated by IGF-I $[133,134]$, at least partially via its signaling target Akt [135]. S1P in turn influences the activities of PI3K and Akt (Fig. 2); this might add an important modulatory loop to the IGF-IR-PI3K signaling. The influence of S1P on PI3K depends on several factors, including PI3K and SphK isoform and its intracellular localization [136]. As mentioned, while pro-apoptotic in some circumstances, S1P produced by SphK2 might also promote cell survival through PI3K-Akt [137]. The interaction of S1P with PI3K-Akt appears to engage nearly the whole repertoire of the sphingolipid's signaling mechanisms. S1PR1 and S1PR3 can activate PI3K and Akt via $\mathrm{G}_{\mathrm{i}}$. S1PR2 ligation may lead to Akt inhibition (probably through $\mathrm{G}_{12 / 13}$ and PTEN), thus the outcome of S1P signaling to IIS via the cell surface is dependent on the cell type [138-142]. However, S1PR2 response includes feedback reduction of the receptor expression [143], probably explaining why S1PR2 can in some situations functionally augment the PI3K-Akt signaling [143, 144]. Kim et al. published data suggesting S1PR-independent, second messenger-like negative effects of S1P on Akt [145].

- The typically negative influence of ceramide on the IISdependent pro-survival signaling [146] includes dephosphorylation of Akt by ceramide-activated protein phosphatase (CAPP) and protein phosphatase 2A (PP2A), followed by modification of Akt subcellular distribution [147, 148]. Inhibition of Akt by C6 ceramide has been shown to involve $\mathrm{PKC} \zeta$ [149]. In turn, PI3K has been shown to block ceramide synthesis [150]. As part of its anti-apoptotic activity, Akt can also modulate ceramide transport between endoplasmic reticulum and Golgi apparatus, additionally influencing ceramide bioavailability for the synthesis of complex sphingolipids [151].

- C1P stimulates the activity of PI3K and Akt, leading to cell proliferation and reduced apoptosis $[152,153]$.

Although highly fragmented and sometimes incoherent, current data suggest extensive engagement of sphingolipid signaling in the modulation of IIS at several levels. Evidence is accumulating that the influence of sphingolipid signaling, mostly observed at relatively upstream levels of the IIS (IGFIR, PI3K, Akt), can indeed lead to meaningful modulation of known aging-related targets of the pathway.

\section{The Divergent Roles of Insulin-Like Growth Factor Signaling (IGF-IR, PI3K, Akt) in Organism Longevity and in Brain Aging: the Potential Role of Sphingolipid Signaling}

The significance of IIS is vast for both physiological aging and the age-related neurodegenerative disorders. Despite of the involvement of the brain IGF-I signaling in the modulation of whole-organism longevity, the influence of IIS on the condition of the brain itself appears to be very different from its role in the periphery, and results are inconsistent [154, 155]. In-depth elucidation of the trophic role of IIS and its dysfunction in brain aging is ongoing [156-158], bridging the numerous gaps in our current understanding of the molecular events leading to the creation of the disease-promoting environment of the aged CNS.

In turn, the groundbreaking discoveries of last decades point to IIS as the crucial pathway that re-directs vital resources towards short-term needs such as energy metabolism, macromolecule synthesis, or survival of individual cells at the expense of the long-term organism maintenance/longevity. Multiple stress stimuli (caloric restriction (CR), starvation, oxidative damage) neutralize the IIS-dependent inhibition of antioxidant defenses (Fig. 2). In nonvertebrates, inactivation of the IIS pathway leads to long-living larval (constitutive dauer) or adult forms, typically displaying high resistance to broad range of stress conditions [159, 160]. The role of IIS in vertebrate longevity appears to follow a relatively similar scheme [161, 162]. Like in lower organisms [163, 164], the longevity effect of IIS inhibition in rodents was dependent on signaling events taking place in neurons [165, 166]. Human data seems to support the role of IIS in lifespan determination, as polymorphisms in IIS genes associate with longevity [167], and centenarians show over-representation of gene variants associated with high circulating IGF-I but reduced IGF-IR activity [168]. However, the matter is still not settled [169], and more research is necessary to characterize in depth the 
boundary between insulin-like signaling and its molecular targets in lifespan determination.

\section{The Significance of Sphingolipid-Dependent Modulation of Longevity-Associated IIS/PI3K/Akt Signaling Mediators and Targets}

Crucial mediators of Akt signaling (Fig. 2) include mTORC1, a protein complex centered around the serine-threonine kinase mechanistic/mammalian target of rapamycin (mTOR). mTORC1 is activated through several branches of the pathway: through phosphorylation of an mTORC1 subunit, through a cascade of inhibitory signals via tuberous sclerosis protein (TSC) and Ras homolog enriched in brain (Rheb), or through IKB kinase $\alpha($ IKK $\alpha)$ [170]. These mTORC1regulating pathways integrate growth factor signals with a vast spectrum of additional factors that reflect cellular metabolic status: oxidative and nitrosative stress, energy/glucose/oxygen levels (sensed, e.g., via AMPK-5' adenosine monophosphateactivated protein kinase, and relayed to Akt and TSC [171-176]), amino acid availability (arginine through TSC [177], and multiple amino acids via indirect signals converging on Rheb and mTORC1 [178]). They also allow cross-talk with $\mathrm{S} 1 \mathrm{P} / \mathrm{C} 1 \mathrm{P} /$ ceramide signaling. Sphingolipids can change mTORC1 activity via their influence on PI3K and Akt, but PI3K-/Akt-independent pathways have also been described (Fig. 2):

- S1P activates mTOR through protein associated with myc (PAM), an E3 ubiquitin ligase [179];

- A phospholipase D-mediated mechanism has been reported where S1P might block mTOR-dependent signaling to S6K and 4E-BP1, leading to enhanced autophagy [180].

mTORC1 and its signaling targets are viewed as a major driving force of numerous cellular processes that contribute to aging, including oxidative catabolism, protein and lipid synthesis, and disturbed free radical defenses [181-183]. mTORC1 is engaged in age-related deregulation of proteostasis, nutrient-dependent signaling, mitochondrial metabolism, and in the acquisition of senescent phenotype (including the pro-inflammatory senescence-associated secretory phenotype (SASP)) $[184,185]$. However, it is worth noting that its positive effects on the respiratory chain [186] can be accompanied by enhanced expression of SOD, catalase, and glutathione peroxidase (GPx) [187].

Changes in mTOR signaling mediate multiple effects of caloric restriction [185]. mTORC1 inhibitor rapamycin is an extremely robust pharmacological treatment that extends lifespan in multiple model organisms, including mammals, even if administered relatively late [185]. Mutation analysis and microRNA research confirm the role of mTOR [188,
189]. The outstanding universality of the lifespan effects of rapamycin have led to suggestions about potential human intervention candidate [185].

The best characterized mediators of mTORC1-dependent actions include S6K1 and S6K2 (ribosomal protein S6 kinases), 4E-BPs (eukaryotic translation initiation factor 4Ebinding proteins), and FOXO transcription factors, but also $\mathrm{NF}-\mathrm{KB}$ and its interaction partners increasingly seem to play important roles (Fig. 3):

- S6K1 and S6K2 are mTORC1-activated stimulators of protein synthesis. Disruption of S6K1 extends lifespan in mice and recapitulates metabolic aspects of CR (including altered gene expression patterns, insulin sensitivity, and glucose tolerance), suggesting the kinase as a crucial mediator of the robust lifeprolonging intervention [193, 194]. Partial inhibition of sphingolipid biosynthesis (pharmacological or genetic reduction of SPT activity) increases yeast cell chronological lifespan through Sch9, an ortholog of S6K $[25,195]$. The topic has not been characterized directly in mammals, but experimental data suggest links between sphingolipids and S6K-dependent modulation of aging. Ceramide leads to S6K inhibition [196]; moreover, altered proportions of ceramide species and the resulting disruption of Akt to S6K1 signaling has been suggested to underlie an important aspect of muscle aging - the loss of adaptability to physical effort [197]. The influence of S1P or FTY720/fingolimod on PI3K (positive or negative, depending on the cell type and its S1PRs subset) has been shown to translate respectively into activation or inhibition of S6K [179, 198, 199]. Fingolimod also increases protein levels of mTOR and S6K, and this effect was probably responsible for the reduction of autophagic neuron death [198]. As a feedback mechanism, S6K can block PI3K activation by the insulin receptor. It may sometimes lead to unexpected results such as the presence of activated S6K despite inhibition of the upstream Akt signaling by ceramide [200]. - Phosphorylation of 4E-BP1 and 4E-BP2 by mTORC1 removes their inhibitory influence on the translation regulator eIF4E. Ceramide has been shown to activate 4E-BP1, although not always via Akt/mTOR [201]. 4E-BP participates in a wide spectrum of stressresponse mechanisms [202-206] and mediates the effects of diet (CR/reduced amino acid supply), temperature, and probably IIS manipulation, on nonvertebrate longevity [202, 207, 208]. Its activation protects mammalian tissues against metabolic disturbances associated with age [209] while loss of 4E-BP regulation contributes to the mentioned age-related disruption of muscle adaptation [210]. 


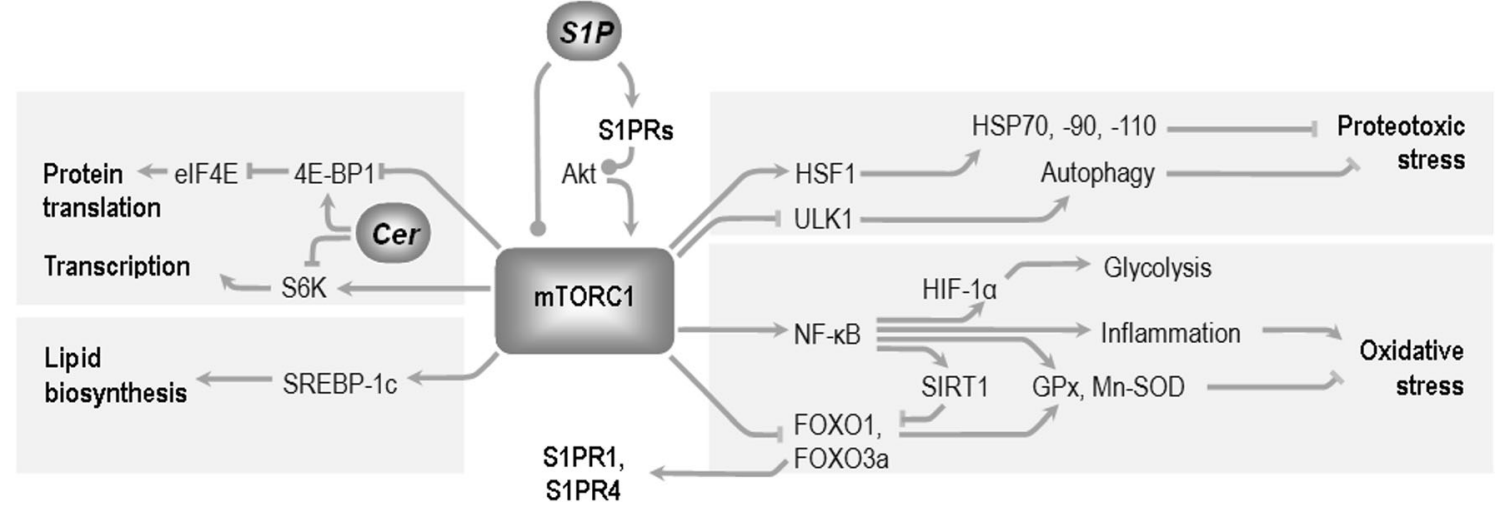

Fig. 3 Selected mediators of mTORC1 signaling in the modulation of cellular metabolism and organism lifespan. Fragmented evidence shows that sphingolipids can lead to opposite effects on mTORC1 activity, depending on the mediators engaged, or experimental model used (see text). The mTORC1 complex influences protein quality assurance mechanisms through heat shock transcription factor 1 (HSF1) and the Unc-51-like kinase (ULK1) [190]. mTORC1 stimulates transcription (via ribosomal S6 kinase (S6K)), and translation (through blocking of $4 \mathrm{E}$ binding protein $4 \mathrm{E}-\mathrm{BP} 1$, which itself is an inhibitor of eukaryotic translation initiation factor 4E-eIF4E). 4E-BP1 can react positively to

- FOXO transcription factors belong to central modulators of IIS/mTOR-dependent stress resistance/lifespan in organisms ranging from nematodes to humans [101, 211, 212]. FOXOs extensively cross-talk with sirtuins (SIRT-1 to 7; homologs of yeast silent information regulator 2) that sense the cellular metabolic status and stress conditions, and orchestrate stress response/ macromolecular repair, influencing the course of aging, neuronal plasticity/learning and memory, and neurodegenerative diseases including $\mathrm{AD}[101,211]$. FOXO1 and FOXO3a typically undergo Akt- or mTORC1-mediated inhibition [213], which neutralizes their numerous homeostatic activities (FOXOs stimulate the expression of catalase, Mn-SOD, GPX, or peroxiredoxin III) [214-217]. Limited evidence suggests that FOXOs might take part in the effects exerted by sphingolipids via IIS. Activation of PI3K and Akt by S1P has been shown to actually trigger the expected downstream events such as inhibitory phosphorylation of FOXO3a or up-regulation of $\mathrm{B}$ cell lymphoma 2 (Bcl-2) and B cell lymphoma-extra large $\left(\mathrm{Bcl}_{\mathrm{XL}}\right)$, leading to impact on the cell survival [218-220]. Interestingly, FOXO1 exerts feedback regulation upon the expression of S1P receptors (S1PR1 and 4) [221].

- NF- $\mathrm{KB}$ is an immune modulator that often contributes to neuronal damage, although the spectrum of its known roles is much wider: sensing oxygen levels, ROS, and RNS (reactive oxygen and nitrogen species) [222-224] (Fig. 2), stimulation of free radical defense, but also of prooxidative enzymes and cell death [225-227]. NF-kB cross-talks with IIS (Fig. the presence of ceramide, although the mechanism has not been fully elucidated. Sterol regulatory element-binding protein (SREBP-1c) mediates the effect of mTOR on lipid biosynthesis [191]. The extremely pleiotropic functions of NF-KB include regulation of the glycolysis-controlling hypoxia inducible factor $1 \alpha(\mathrm{HIF} 1 \alpha)$, sirtuin (SIRT1), and forkhead box O1 transcription factors (FOXOs, which can send feedback signal to S1P receptors), and antioxidative enzymes glutathione peroxidase (GPx) and manganese superoxide dismutase (Mn-SOD). According to [192], modified

2) and is linked with aging modulation, with cellular senescence, and SASP [225, 227-229]. Moreover, disturbances of the NF-KB target HIF- $1 \alpha$ may be responsible for the age-dependent, mitochondria-linked deregulation of energetic metabolism in mammals $[230,231]$. Finally, links of NF-KB and the retrograde response (see below) deserve further attention in the context of aging mechanisms [232].

$\mathrm{S} 1 \mathrm{P}$ activates NF-KB through Akt signaling to either IKK $\alpha$ or mTORC1, leading to modulation of NF- $\mathrm{KB}$ target genes and responses [233-235]. However, the significance of this interaction is unclear due to the NF-KB's above-mentioned role in immune stimulation and cell death - also in the brain [236]. The importance of fine-tuning of various aspects of NF- $\mathrm{KB}$ response to S1P signaling is further stressed by the fact that $\mathrm{S} 1 \mathrm{P}$ and the $\mathrm{S} 1 \mathrm{P}$ receptor modulator fingolimod sometimes paradoxically exert opposite influence on some NF-kB targets such as NO production in astrocytes [236]. Moreover, while some S1P receptors (including S1PR2) activate NF-KB, S1PR5 actually inhibits it, suggesting that the cell type and its relative expression levels of various S1PR isoforms can switch the outcome of S1P signaling [235, 237].

The poorly characterized C1P receptor allows also $\mathrm{C} 1 \mathrm{P}$ to stimulate DNA binding by NF-KB via PI3K and Akt [152, 153].

Interestingly, DNA binding by NF- $\mathrm{KB}$ is also increased in response to a cell-permeable short-chain analog of ceramide, though this response did not lead to increase in the measured gene activities [238]. The significance of high levels of endogenous, C16:0 and C20:0 ceramides for 
NF- $\mathrm{KB}$ has been confirmed by Rivas et al., who found elevated expression of the transcription factor in old muscle, where it probably contributed to the age-related attenuation of the tissue adaptability to exercise [197]. NF-KB exerts feedback responses on various levels of sphingolipid signaling, mainly through up-regulation of SPT and acid sphingomyelinase, but also S1P phosphatase [239-241].

\section{The Retrograde Response as an Example of Sphingolipid Role in Aging/Senescence}

The significance of the cross-talk between sphingolipids and the IIS-dependent modulation of stress defense has also been analyzed in the context of the retrograde response that signals, e.g., the presence of defective mitochondria, a crucial element of aging, to the nucleus [242]. TORC1 senses the cellular nutrient status, and when glutamate is lacking, reduced TORC1 activity leads to de-repression of the retrograde response, which interacts with the regulatory pathways of mitophagy. Mitophagy is a subset of autophagic organelle degradation, and its proper regulation ensures that defective mitochondria are eliminated leaving the best-preserved organelles for replication. The retrograde response is known to be involved in yeast cell lifespan extension. Its crucial significance for the long-term cellular maintenance has led to the suggestion that the longevityrelated function of yeast LAG1 and its worm orthologs $h y l-1$ and hyl-2 in fact stemmed from their significance in the integration of these mitochondrial quality signaling pathways [243]. The link between the detection of defects by the retrograde response and the execution of mitophagy involves sphingolipid signaling (LAG ceramide synthases, ceramidases), TOR, and a TORC1interacting ortholog of mammalian S6K [243]. Mammalian orthologs of the retrograde response pathway proteins also include NF-kB. The mechanism appears to be related to elements of the mammalian unfolded protein response and endoplasmic reticulum stress $[243,244]$. The importance of degradation of defective mitochondria for neuronal cell maintenance makes it a promising aging research target, although there is a clear difference in the observed effects between rodents and humans [245]. The wide-ranging longevity effects of mild mitochondrial uncoupling/ coenzyme $\mathrm{Q}$ synthesis manipulation via reduced MCLK1 (5-demethoxyubiquinone hydroxylase) gene expression suggest the existence of retrograde-type signaling in vertebrates [244]. However, the identity of mammalian proteins that signal mitochondrial damage to the nucleus is still not well understood [246].
Sphingolipids and Mitochondrial Number/Quality Control

The role of mitochondria in cell death signaling by ceramide has been reviewed extensively [247, 248]. However, evidence is accumulating on ceramide roles in a whole spectrum of regulatory events that affect their function. In mammalian oocytes disturbed intracellular localization of ceramide (due to loss of ceramide transport protein expression) seems to contribute to loss of mitochondrial function with oocyte age, which may be an important example of links between sphingolipid metabolism and long-term cellular homoeostasis [249].

Maintenance of mitochondrial dynamics is crucial for cell cell health. Non-symmetrical fission allows sequestration of damaged, dysfunctional, or "worn" mitochondrial material, which can be degraded in the process of mitophagy, while fusion allows amassing healthy organelles. Sphingolipid signaling has tight ties with mitochondrial dynamics. The levels of sphingoid bases which serve as sphingolipid precursors increases with yeast chronological aging, and these compounds inhibit mitochondrial fusion, leading to fragmentation and to age-related symptoms of mitochondrial decay (Fig. 4) [250]. Ceramide has been shown to activate fission of mitochondria in various tissues and in a cellular model, acting through modulation of expression levels of BOK (Bcl-2-related ovarian killer

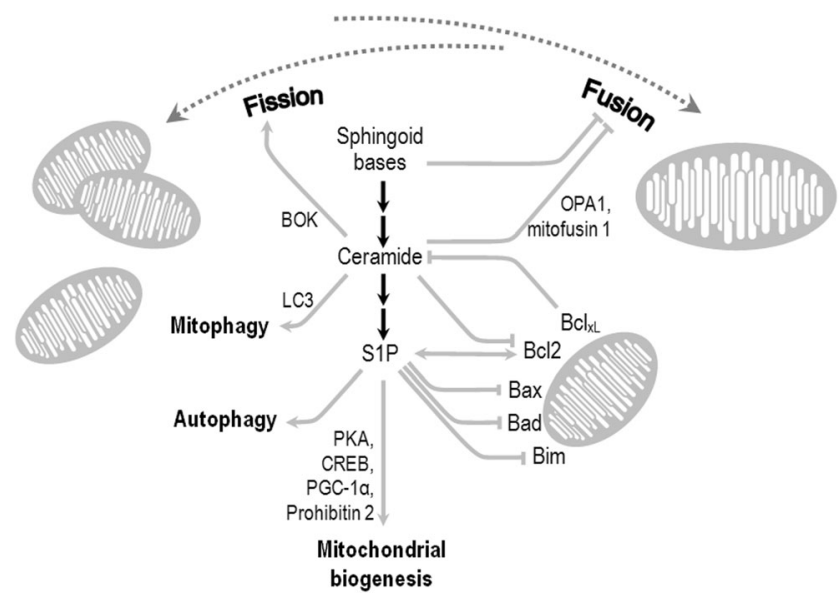

Fig. 4 Bioactive sphingolipids and their roles in mitochondrial fusion, fission, autophagy/mitophagy, and apoptotic signaling. Ceramide is capable of activating mitophagy (via microtubule-associated protein 1A/1B-light chain 3 proteins (LC3)) and mitochondrial fission (through Bcl-2-related ovarian killer protein (BOK)), while inhibiting fusion (through mitofusin 1 and the optic atrophy protein (OPA1); see text for details. S1P generally activates autophagy, although the significance of this fact for mitochondrial turnover is not yet known. However, S1P augments mitochondrial assembly via protein kinase A (PKA), peroxisome proliferator-activated receptor gamma coactivator 1 (PGC$1 \alpha$ ), and prohibitin 2. S1P and ceramide regulate the anti-apoptotic Bcl-2 and the $\mathrm{Bcl}-2$ family protein: $\mathrm{Bcl}_{\mathrm{xL}}$, and pro-apoptotic $\mathrm{Bax}$, Bad, or Bim. In turn, some of the proteins influence the enzymes of sphingolipid metabolism, ensuring negative or positive feedback regulation 
protein) [251]. Ceramide inhibits Akt signaling (synergistically with intracellular amyloid $\beta_{42}\left(\mathrm{~A} \beta_{42}\right)$ ) and disturbs the fusion-fission regulation in neuronal cell lines through down-regulation of the fusion-promoting proteins mitofusin 1 and OPA1 (optic atrophy 1) [252] (Fig. 4). Ceramide also reduced the levels of the fission regulator dynamin-related protein 1 , although in muscle cells its seemed to exert opposite effect [252, 253]. Likewise, loss of the ceramide transfer protein CERT results in disturbed transport of ceramides from endoplasmic reticulum to Golgi apparatus, hexosylceramide accumulation in mitochondria, and lower frequency of both fusion and fission [254]. Finally, like in the plasma membrane, ceramide plays important structural roles in raft-like domains, and their disruption through inhibition of ceramide synthase disturbs the fission process [255].

Mitophagy, the mitochondria-targeting subset of autophagy, can be triggered by signs of organellar decay such as ROS generation or loss of mitochondrial membrane potential. The resulting autophagosome fuses with lysosome to create autophagolysosome, a process dependent on the LC3 (microtubule-associated protein 1A/1B-light chain 3) proteins. Mitophagy may result in either homoeostatic removal of damaged mitochondria, or escalate into various modes of cell death, depending on the circumstances. LC3 proteins interact with ceramide in mitochondrial membranes in an selective way dependent on the LC3 isoform, and this interaction facilitates autophagosome binding [256]. Besides other cellular sources, ceramide can be produced in mitochondria at least in some tissues; enzymes of its metabolism including CerS, sphingomyelinase, and ceramidase have been detected in isolated mitochondria [257-259]. Ceramide's role in mitophagy can extend to mitophagic cell death [260].

Limited data suggests the involvement of SphKs in autophagy in general [180], suggesting possible links with mitochondrial quality assurance mechanisms. Moreover, S1P has been shown to activate mitochondrial biogenesis and adenosine triphosphate (ATP) generation via S1PR2, the protein kinase A (PKA)/cAMP response element-binding protein (CREB) pathway, and peroxisome proliferator-activated receptor $\gamma$ coactivator $1 \alpha(\mathrm{PGC}-1 \alpha)$ [261]. Mitochondrial assembly and the respiratory chain function are also dependent upon S1P binding to the prohibitin 2 protein [262]. Major part of S1P's anti-apoptotic signaling occurs through its influence on mitochondria-associating proteins of the Bcl-2 family. S1P increases Bcl-2 level [263] and phosphorylation [264], leading to inhibition of apoptosis. S1P also down-regulates Bcl2associated X protein (Bax), Bad, and Bim (BCL2-like 11 protein) $[263,265,266]$. In turn, $\mathrm{Bcl}-2$ and $\mathrm{Bcl}_{\mathrm{xL}}$ inhibit ceramide synthesis by nSMase [267]. Interestingly, Bcl-2 also increases SphK1 level and activity [268], and Bax/Bak activates CerS [269]. Although IIS is a classical regulator of survival, some of the mentioned effects are not mediated by PI3K/Akt signaling. SphK2-synthesized S1P promotes autophagy and the associated tissue tolerance to neurodegenerative ischemic insult (preconditioning in cortical neurons) [270], but it remains to be investigated how it would translate to any actual links with mitophagy.

\section{Sphingolipids in the Alzheimer's Disease}

Accumulating evidence points to the involvement of sphingolipids in the neurodegeneration in AD. Hippocampal ceramide and sphingomyelin content correlate with age in men and aging in females leads to reduction in the fraction of phosphorylated sphingosine (S1P/sphingosine ratio), suggesting that age-related changes in bioactive sphingolipids might create pro-apoptotic, neurodegeneration-conductive environment [83]. Imbalance in the S1P and ceramide, which potentially might decide of the brain cell fates is observed from the earliest clinically recognizable stages of $\mathrm{AD}$ and

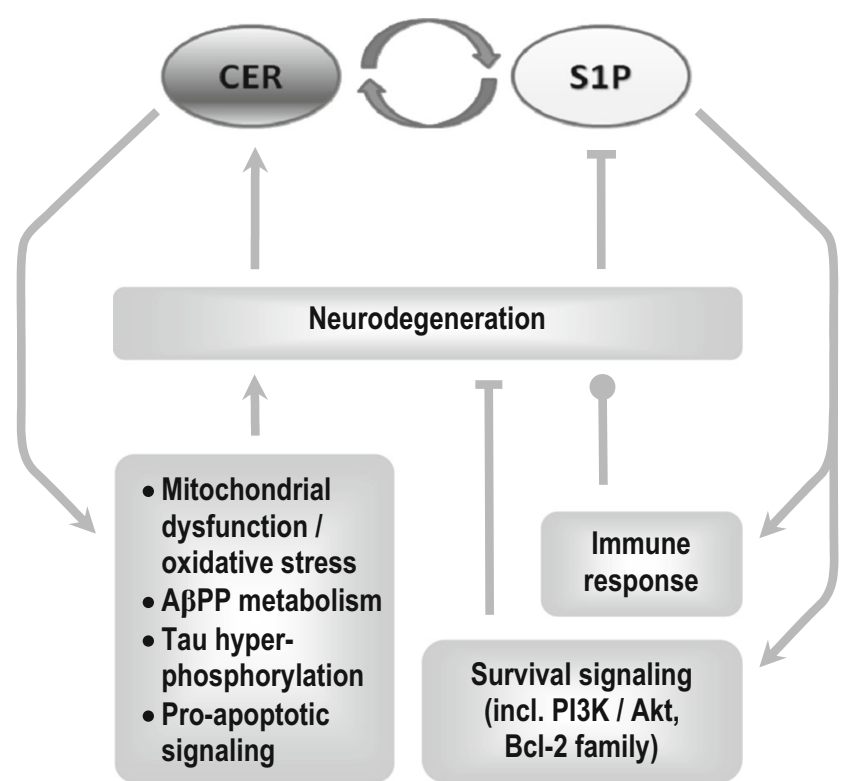

Fig. 5 The significance of bioactive sphingolipids in neurodegeneration. The 'sphingolipid rheostat' model assumes antagonistic roles of ceramide and S1P in the regulation of cellular survival and death. Although exceptions have been identified, the tendency towards accumulation of ceramide and reduced levels of S1P still should generate strong neurodegenerative impulse. Potential downstream mechanisms include not only inhibition of survival signaling mostly mediated by the PI3KAkt pathway, but also modulation of $A \beta P P$ metabolism, and alteration of S1PR-dependent immune response - the latter capable of exerting either beneficial (A $\beta$ clearance) or detrimental outcome (damage to neurons). symbol denotes the ambiguous role of immune activation in neurodegenerative disorders (clearance of extracellular aggregates of misfolded proteins and debris from dying cells vs. creation of neurotoxic environment that accelerates the loss of neuronal connectivity and ultimately death of further neurons). S1P is known to modulate the immune response, but the possible outcome of the resulting reaction in the diseased brain is highly unclear 
correlates with Braak staging of neurodegenerative changes (Table 1) $[76,79]$. The presence of a very early peak in ceramide generation in the brain has led to a proposal of a premild cognitive impairment (MCI) stage of $\mathrm{AD}$ development [86]. The observed changes in sphingomyelin are less coherent [92]. However, using autopsy material from the Baltimore Longitudinal Study of Aging, Varma et al. have noted that three sphingomyelin species and one hydroxysphingomyelin associated with the progression along the prodromal and preclinical stages of AD. Moreover, higher levels of identified sphingomyelins and hydroxysphingomyelin associate with the risk of future conversion to AD [81]. The association of sphingolipid levels with either early AD stages, and the accessibility of body fluids for diagnostic purposes have led to suggestions of sphingolipids as potential AD biomarkers useful for early risk identification/diagnosis. Toledo et al. have found that some serum sphingomyelin species correlate with progression from $\mathrm{MCI}$ to full $\mathrm{AD}$ [82]. Likewise, the enzymes of sphingolipid metabolism are altered in $\mathrm{AD}$ in a manner correlating with disease progression. Examples of upregulated genes include the ceramide-producing synthases LASS1, LASS2 (coding for CerS1 and CerS2, respectively) and acid sphingomyelinase $A S M$; S1P lyase SGPL1, and serine palmitoyltransferase SPTLC2 (which decides on the general ceramide/sphingolipid levels) were also increased, while the acid ceramidase $A S A H 1, \mathrm{C} 1 \mathrm{P}$-generating $C E R K$, or-less obviously_LASS6 are reduced $[76,77]$. We confirmed the trend towards reduced expression of S1P- and C1Pproducing enzymes (SPHKs, CERK, $\mathrm{S} 1 \mathrm{P}$ receptors) in human sporadic AD brains although there were slight differences in the types of genes/isoforms affected [271].

The roles of S1P and ceramide in the survival of brain neurons are far more complex than the antagonism described in the sphingolipid rheostat model. However, it is highly probable that changes in these compounds should significantly alter the rates of neuron degeneration and death (Fig. 5). Modulation of IIS activity largely mediates the pro- or antiapoptotic signaling of S1P, C1P, and ceramide. IGF-I resistance may be an important aspect of AD pathology, although over-activation of the pathway has also been suggested to contribute [272, 273]. Microglial expression of IGF-I reduces $\mathrm{A} \beta$ release and inflammation [274, 275], and IGF-I prevents $\mathrm{A} \beta_{25-35}$-induced hippocampal neuron death [276]. Human IGF-I-expressing cortex-derived neural stem cells have been proposed for AD therapy [277]. S1PR signaling can inhibit GSK-3 $\beta$, the kinase engaged in tau phosphorylation, via PI3K-Akt [17]. S1P has been also shown to inhibit $A \beta$ dependent ceramide production by aSMase [278], although prolonged production of S1P by SPHK2 can lead to neurodegeneration $[4,40]$. The roles of S1P in the regulation of secretion mechanisms also deserve more attention in the context of extracellular protein neurotoxicity $[1,279]$. The pattern of sphingolipid metabolic enzyme changes in $\mathrm{AD}$ can be largely replicated in an animal $\mathrm{A} \beta$ precursor protein $(\mathrm{A} \beta \mathrm{PP}$, V717I)-transfected model, suggesting that these alterations arise in a relatively direct way in response to high $\mathrm{A} \beta$ peptide production [271]. Fingolimod effects on the age-dependent transcription of survival-regulating sphingolipid metabolism genes supports the need of its in-depth characterization as a potential disease-modifying treatment in $\mathrm{AD}$ and other neurodegenerative disorders [271].

\section{Concluding Remarks}

Sphingolipids and sphingolipid metabolism are being increasingly implicated in aging and in age-related neurodegenerative disorders. The mechanisms of their engagement include both modulatory influences on membrane microenvironments (importantly, lipid rafts) as structural components, and interactions with signaling pathways. Crucially for aging and neurodegeneration, sphingolipids modulate neurotransmission and hormonal regulation. Sphingolipids' cross-talk with the IGF-I-Akt-mTOR pathway may modulate multiple aspects of cellular survival, stress response, and aging. The potential significance of these interactions is vast and might include opportunities for therapeutic interventions. However, the depiction of sphingolipid engagement in long-term homoeostasis, requires much more comprehensive understanding. Currently available means of intervention involving sphingolipids need to be better understood and clinically refined before the compromise between their side-effects and the possible benefits becomes a viable option.

Acknowledgments This work was supported by the National Science Centre (PL) grant no. NCN 2014/15/B/NZ3/01049.

\section{Compliance with Ethical Standards}

Conflict of Interest The authors declare that they have no conflict of interest.

Open Access This article is distributed under the terms of the Creative Commons Attribution 4.0 International License (http:// creativecommons.org/licenses/by/4.0/), which permits unrestricted use, distribution, and reproduction in any medium, provided you give appropriate credit to the original author(s) and the source, provide a link to the Creative Commons license, and indicate if changes were made.

\section{References}

1. Karunakaran I, van Echten-Deckert G (2017) Sphingosine 1-phosphate - a double edged sword in the brain. Biochim Biophys Acta 1859:1573-1582. https://doi.org/10.1016/j.bbamem.2017.03.008

2. Kanno T, Nishizaki T, Proia RL, Kajimoto T, Jahangeer S, Okada T, Nakamura S (2010) Regulation of synaptic strength by 
sphingosine 1-phosphate in the hippocampus. Neuroscience 171: 973-980. https://doi.org/10.1016/j.neuroscience.2010.10.021

3. Van Brocklyn JR, Williams JB (2012) The control of the balance between ceramide and sphingosine-1-phosphate by sphingosine kinase: oxidative stress and the seesaw of cell survival and death. Comp Biochem Physiol B: Biochem Mol Biol 163:26-36. https:// doi.org/10.1016/j.cbpb.2012.05.006

4. Ghasemi R, Dargahi L, Ahmadiani A (2016) Integrated sphingosine-1 phosphate signaling in the central nervous system: from physiological equilibrium to pathological damage. Pharmacol Res 104:156-164. https://doi.org/10.1016/j.phrs. 2015.11.006

5. Astudillo L, Sabourdy F, Therville N, Bode H, Ségui B, AndrieuAbadie N, Hornemann T, Levade T (2015) Human genetic disorders of sphingolipid biosynthesis. J Inherit Metab Dis 38:65-76. https://doi.org/10.1007/s10545-014-9736-1

6. Schulze H, Sandhoff K (2014) Sphingolipids and lysosomal pathologies. Biochim Biophys Acta 1841:799-810. https://doi.org/ 10.1016/j.bbalip.2013.10.015

7. Sabourdy F, Astudillo L, Colacios C, Dubot P, Mrad M, Ségui B, Andrieu-Abadie N, Levade T (2015) Monogenic neurological disorders of sphingolipid metabolism. Biochim Biophys Acta 1851: 1040-1051. https://doi.org/10.1016/j.bbalip.2015.01.010

8. Alvarez SE, Harikumar KB, Hait NC, Allegood J, Strub GM, Kim EY, Maceyka M, Jiang H et al (2010) Sphingosine-1-phosphate is a missing cofactor for the E3 ubiquitin ligase TRAF2. Nature 465: 1084-1088. https://doi.org/10.1038/nature09128

9. Contreras F-X, Ernst AM, Haberkant P, Björkholm P, Lindahl E, Gönen B, Tischer C, Elofsson A et al (2012) Molecular recognition of a single sphingolipid species by a protein's transmembrane domain. Nature 481:525-529. https://doi.org/10.1038/ nature 10742

10. Colombini M (2017) Ceramide channels and mitochondrial outer membrane permeability. J Bioenerg Biomembr 49:57-64. https:// doi.org/10.1007/s10863-016-9646-Z

11. Jazvinšćak Jembrek M, Hof PR, Šimić G (2015) Ceramides in Alzheimer's disease: key mediators of neuronal apoptosis induced by oxidative stress and Abeta accumulation. Oxidative Med Cell Longev 2015:346783. https://doi.org/10.1155/2015/346783

12. Snook CF, Jones JA, Hannun YA (2006) Sphingolipid-binding proteins. Biochim Biophys Acta 1761:927-946. https://doi.org/ 10.1016/j.bbalip.2006.06.004

13. van Blitterswijk WJ, van der Luit AH, Veldman RJ, Verheij M, Borst J (2003) Ceramide: second messenger or modulator of membrane structure and dynamics? Biochem J 369:199-121. https:// doi.org/10.1042/BJ20021528

14. Krönke M (1999) Biophysics of ceramide signaling: interaction with proteins and phase transition of membranes. Chem Phys Lipids 101:109-121

15. Bidlingmaier S, Ha K, Lee N-K, Su Y, Liu B (2016) Proteomewide identification of novel ceramide-binding proteins by yeast surface cDNA display and deep sequencing. Mol Cell Proteomics 15:1232-1245. https://doi.org/10.1074/mcp.M115.055954

16. Elsen L, Betz R, Schwarzmann G, Sandhoff K, van EchtenDeckert G (2002) Identification of ceramide binding proteins in neuronal cells: a critical point of view. Neurochem Res 27:717727

17. Wang Y, Yang R, Gu J, Yin X, Jin N, Xie S, Wang Y et al (2015) Cross talk between PI3K-AKT-GSK-3 $\beta$ and PP2A pathways determines tau hyperphosphorylation. Neurobiol Aging 36:188200. https://doi.org/10.1016/j.neurobiolaging.2014.07.035

18. Hoeferlin LA, Fekry B, Ogretmen B, Krupenko SA, Krupenko NI (2013) Folate stress induces apoptosis via p53-dependent de novo ceramide synthesis and up-regulation of ceramide synthase 6 . J Biol Chem 288:12880-12890. https://doi.org/10.1074/jbc.M113. 461798
19. Ghosh S, Bhattacharyya S, Sirkar M, Sa GS, Das T, Majumdar D, Roy S, Majumdar S (2002) Leishmania donovani suppresses activated protein 1 and NF-kappaB activation in host macrophages via ceramide generation: involvement of extracellular signalregulated kinase. Infect Immun 70:6828-6838

20. Mesicek J, Lee H, Feldman T, Jiang X, Skobeleva A, Berdyshev EV, Haimovitz-Friedman A, Fuks Z et al (2010) Ceramide synthases 2, 5, and 6 confer distinct roles in radiation-induced apoptosis in HeLa cells. Cell Signal 22:1300-1307. https://doi. org/10.1016/j.cellsig.2010.04.006

21. Cruickshanks N, Roberts JL, Bareford MD, Tavallai M, Poklepovic A, Booth L, Spiegel S, Dent P (2015) Differential regulation of autophagy and cell viability by ceramide species. Cancer Biol Ther 16:733-742. https://doi.org/10.1080/ 15384047.2015.1026509

22. Lahiri S, Lee H, Mesicek J, Fuks Z, Haimovitz-Friedman A, Kolesnick RN, Futerman AH (2007) Kinetic characterization of mammalian ceramide synthases: determination of $\mathrm{K}(\mathrm{m})$ values towards sphinganine. FEBS Lett 581:5289-5294. https://doi.org/ 10.1016/j.febslet.2007.10.018

23. Siddique MM, Li Y, Chaurasia B, Kaddai VA, Summers SA (2015) Dihydroceramides: from bit players to lead actors. J Biol Chem 290:15371-15379. https://doi.org/10.1074/jbc.R115. 653204

24. Breen P, Joseph N, Thompson K, Kraveka JM, Gudz TI, Li L, Rahmaniyan M, Bielawski J et al (2013) Dihydroceramide desaturase knockdown impacts sphingolipids and apoptosis after photodamage in human head and neck squamous carcinoma cells. Anticancer Res 33:77-84

25. Huang X, Withers BR, Dickson RC (2014) Sphingolipids and lifespan regulation. Biochim Biophys Acta 1841:657-664. https://doi.org/10.1016/j.bbalip.2013.08.006

26. Ong W-Y, Herr DR, Farooqui T, Ling E-A, Farooqui AA (2015) Role of sphingomyelinases in neurological disorders. Expert Opin Ther Targets 19:1725-1742. https://doi.org/10.1517/14728222. 2015.1071794

27. Haughey NJ, Bandaru VVR, Bae M, Mattson MP (2010) Roles for dysfunctional sphingolipid metabolism in Alzheimer's disease neuropathogenesis. Biochim Biophys Acta 1801:878-886. https:// doi.org/10.1016/j.bbalip.2010.05.003

28. Xu R, Wang K, Mileva I, Hannun YA, Obeid LM, Mao C (2016) Alkaline ceramidase 2 and its bioactive product sphingosine are novel regulators of the DNA damage response. Oncotarget 7: 18440-18457. https://doi.org/10.18632/oncotarget.7825

29. Viani P, Giussani P, Riboni L, Bassi R, Tettamanti G (1999) Sphingosine inhibits nitric oxide synthase from cerebellar granule cells differentiated in vitro. FEBS Lett 454:321-324

30. Park J-W, Pewzner-Jung Y (2013) Ceramide synthases: reexamining longevity. Handb Exp Pharmacol:89-107. https:// doi.org/10.1007/978-3-7091-1368-4 5

31. Novgorodov SA, Riley CL, Keffler JA, Yu J, Kindy MS, Macklin WB, Lombard DB, Gudz TI (2016) SIRT3 deacetylates ceramide synthases: implications for mitochondrial dysfunction and brain injury. J Biol Chem 291:1957-1973. https://doi.org/10.1074/jbc. M115.668228

32. Motyl J, Przykaza $~$, Boguszewski PM, Kosson P, Strosznajder JB (2018) Pramipexole and Fingolimod exert neuroprotection in a mouse model of Parkinson's disease by activation of sphingosine kinase 1 and Akt kinase'. Neuropharmacology. https://doi.org/10. 1016/j.neuropharm.2018.02.023

33. Di Pardo A, Amico E, Basit A, Armirotti A, Joshi P, Neely DM, Vuono R, Castaldo S et al (2017) Defective sphingosine-1phosphate metabolism is a druggable target in Huntington's disease. Sci Rep 7:5280. https://doi.org/10.1038/s41598-017-05709$\mathrm{y}$ 
34. Joly S, Dalkara D, Pernet V (2017) Sphingosine 1-phosphate receptor 1 modulates CNTF-induced axonal growth and neuroprotection in the mouse visual system. Neural Plast 2017:6818970. https://doi.org/10.1155/2017/6818970

35. Safarian F, Khallaghi B, Ahmadiani A, Dargahi L (2015) Activation of $\mathrm{S}_{1} \mathrm{P}_{1}$ receptor regulates $\mathrm{PI} 3 \mathrm{~K} / \mathrm{Akt} / \mathrm{FoxO} 3$ a pathway in response to oxidative stress in PC12 cells. J Mol Neurosci 56: 177-187. https://doi.org/10.1007/s12031-014-0478-1

36. Xia P, Wang L, Moretti PAB, Albanese N, Chai F, Pitson SM, D'Andrea RJ, Gamble JR et al (2002) Sphingosine kinase interacts with TRAF2 and dissects tumor necrosis factor-alpha signaling. J Biol Chem 277:7996-8003. https://doi.org/10.1074/jbc. M111423200

37. Huang K, Huang J, Chen C, Hao J, Wang S, Huang J, Liu P, Huang H (2014) AP-1 regulates sphingosine kinase 1 expression in a positive feedback manner in glomerular mesangial cells exposed to high glucose. Cell Signal 26:629-638. https://doi.org/10. 1016/j.cellsig.2013.12.002

38. Wegner M-S, Wanger RA, Oertel S, Brachtendorf S, Hartmann D, Schiffmann S, Marschalek R, Schreiber Y et al (2014) Ceramide synthases CerS4 and CerS5 are upregulated by $17 \beta$-estradiol and GPER1 via AP-1 in human breast cancer cells. Biochem Pharmacol 92:577-589. https://doi.org/10.1016/j.bcp.2014.10. 007

39. O'Neill SM, Houck KL, Yun JK, Fox TE, Kester M (2011) AP-1 binding transcriptionally regulates human neutral ceramidase. Arch Biochem Biophys 511:31-39. https://doi.org/10.1016/j. abb.2011.04.009

40. Hagen N, Hans M, Hartmann D, Swandulla D, van Echten-Deckert G (2011) Sphingosine-1-phosphate links glycosphingolipid metabolism to neurodegeneration via a calpain-mediated mechanism. Cell Death Differ 18:1356-1365. https://doi.org/10.1038/cdd. 2011.7

41. Vesely PW, Staber PB, Hoefler G, Kenner L (2009) Translational regulation mechanisms of AP-1 proteins. Mutat Res 682:7-12. https://doi.org/10.1016/j.mrrev.2009.01.001

42. Sawe N, Steinberg G, Zhao H (2008) Dual roles of the MAPK/ ERK1/2 cell signaling pathway after stroke. J Neurosci Res 86: 1659-1669. https://doi.org/10.1002/jnr.21604

43. Subramaniam S, Unsicker K (2010) ERK and cell death: ERK1/2 in neuronal death. FEBS J 277:22-29. https://doi.org/10.1111/j. 1742-4658.2009.07367.x

44. Wang L, Cheng B-F, Yang H-J, Wang M, Feng Z-W (2015) NF$\mathrm{KB}$ protects human neuroblastoma cells from nitric oxide-induced apoptosis through upregulating biglycan. Am J Transl Res 7: $1541-1552$

45. Kim A, Nam YJ, Lee CS (2017) Taxifolin reduces the cholesterol oxidation product-induced neuronal apoptosis by suppressing the Akt and NF-kB activation-mediated cell death. Brain Res Bull 134:63-71. https://doi.org/10.1016/j.brainresbull.2017.07.008

46. Chan H, Pitson SM (2013) Post-translational regulation of sphingosine kinases. Biochim Biophys Acta 1831:147-156. https://doi. org/10.1016/j.bbalip.2012.07.005

47. Neubauer HA, Pitson SM (2013) Roles, regulation and inhibitors of sphingosine kinase 2. FEBS J 280:5317-5336. https://doi.org/ 10.1111/febs. 12314

48. Mahajan-Thakur S, Bien-Möller S, Marx S, Schroeder H, Rauch BH (2017) Sphingosine 1-phosphate (S1P) signaling in glioblastoma multiforme - a systematic review. Int J Mol Sci 18. https:// doi.org/10.3390/ijms 18112448

49. Ebenezer DL, Fu P, Suryadevara V, Zhao Y, Natarajan V (2017) Epigenetic regulation of pro-inflammatory cytokine secretion by sphingosine 1-phosphate (S1P) in acute lung injury: Role of S1P lyase. Adv Biol Regul 63:156-166. https://doi.org/10.1016/j.jbior. 2016.09.007
50. Hammad SM, Pierce JS, Soodavar F, Smith KJ, Al Gadban MM, Rembiesa B, Klein RL, Hannun YA et al (2010) Blood sphingolipidomics in healthy humans: impact of sample collection methodology. J Lipid Res 51:3074-3087. https://doi.org/10.1194/ jlr.D008532

51. Farooqui AA, Ong W-Y, Farooqui T (2010) Lipid mediators in the nucleus: their potential contribution to Alzheimer's disease. Biochim Biophys Acta 1801:906-916. https://doi.org/10.1016/j. bbalip.2010.02.002

52. Maiese K, Chong ZZ, Wang S, Shang YC (2012) Oxidant stress and signal transduction in the nervous system with the PI 3-K, Akt, and mTOR cascade. Int J Mol Sci 13:13830-13866. https:// doi.org/10.3390/ijms 131113830

53. O'Sullivan S, Dev KK (2017) Sphingosine-1-phosphate receptor therapies: advances in clinical trials for CNS-related diseases. Neuropharmacology 113:597-607. https://doi.org/10.1016/j. neuropharm.2016.11.006

54. Choi JW, Chun J (2013) Lysophospholipids and their receptors in the central nervous system. Biochim Biophys Acta 1831:20-32. https://doi.org/10.1016/j.bbalip.2012.07.015

55. Yue X, Jin H, Liu H, Rosenberg AJ, Klein RS, Tu Z (2015) A potent and selective C-11 labeled PET tracer for imaging sphingosine-1-phosphate receptor 2 in the CNS demonstrates sexually dimorphic expression. Org Biomol Chem 13:7928-7939. https://doi.org/10.1039/c5ob00951k

56. Silva VRR, Katashima CK, Bueno Silva CG, Lenhare L, Micheletti TO, Camargo RL, Ghezzi AC, Camargo JA et al (2016) Hypothalamic S1P/S1PR1 axis controls energy homeostasis in middle-aged rodents: the reversal effects of physical exercise. Aging (Albany NY) 9:142-155. https://doi.org/10.18632/ aging. 101138

57. Gruber HE, Hoelscher GL, Ingram JA, Zinchenko N, Hanley EN (2010) Senescent vs. non-senescent cells in the human annulus in vivo: cell harvest with laser capture microdissection and gene expression studies with microarray analysis. BMC Biotechnol 10:5. https://doi.org/10.1186/1472-6750-10-5

58. Park SW, Kim M, Brown KM, D'Agati VD, Lee HT (2012) Inhibition of sphingosine 1-phosphate receptor 2 protects against renal ischemia-reperfusion injury. J Am Soc Nephrol 23:266-280. https://doi.org/10.1681/ASN.2011050503

59. Hait NC, Allegood J, Maceyka M, Strub GM, Harikumar KB, Singh SK, Luo C, Marmorstein R et al (2009) Regulation of histone acetylation in the nucleus by sphingosine-1-phosphate. Science 325:1254-1257. https://doi.org/10.1126/science.1176709

60. Newton J, Hait NC, Maceyka M, Colaco A, Maczis M, Wassif CA, Cougnoux A, Porter FD et al (2017) FTY720/fingolimod increases NPC1 and NPC2 expression and reduces cholesterol and sphingolipid accumulation in Niemann-Pick type $\mathrm{C}$ mutant fibroblasts. FASEB J 31:1719-1730. https://doi.org/10.1096/fj. 201601041R

61. Moruno-Manchon JF, Uzor N-E, Blasco-Conesa MP, Mannuru S, Putluri N, Furr-Stimming EE, Tsvetkov AS (2017) Inhibiting sphingosine kinase 2 mitigates mutant Huntingtin-induced neurodegeneration in neuron models of Huntington disease. Hum Mol Genet 26:1305-1317. https://doi.org/10.1093/hmg/ddx046

62. Arana L, Gangoiti P, Ouro A, Trueba M, Gómez-Muñoz A (2010) Ceramide and ceramide 1-phosphate in health and disease. Lipids Health Dis 9:15. https://doi.org/10.1186/1476-511X-9-15

63. Gomez-Muñoz A, Presa N, Gomez-Larrauri A, Rivera I-G, Trueba M, Ordoñez M (2016) Control of inflammatory responses by ceramide, sphingosine 1-phosphate and ceramide 1-phosphate. Prog Lipid Res 61:51-62. https://doi.org/10.1016/j.plipres.2015. 09.002

64. Hait NC, Maiti A (2017) The role of Sphingosine-1-phosphate and Ceramide-1-phosphate in inflammation and Cancer. Mediat Inflamm 2017:4806541. https://doi.org/10.1155/2017/4806541 
65. Presa N, Gomez-Larrauri A, Rivera I-G, Ordoñez M, Trueba M, Gomez-Muñoz A (2016) Regulation of cell migration and inflammation by ceramide 1-phosphate. Biochim Biophys Acta 1861: 402-409. https://doi.org/10.1016/j.bbalip.2016.02.007

66. Gómez-Muñoz A, Kong JY, Salh B, Steinbrecher UP (2004) Ceramide-1-phosphate blocks apoptosis through inhibition of acid sphingomyelinase in macrophages. J Lipid Res 45:99-105. https://doi.org/10.1194/jlr.M300158-JLR200

67. Granado MH, Gangoiti P, Ouro A, Arana L, Gómez-Muñoz A (2009) Ceramide 1-phosphate inhibits serine palmitoyltransferase and blocks apoptosis in alveolar macrophages. Biochim Biophys Acta 1791:263-272. https://doi.org/10.1016/j.bbalip.2009.01.023

68. Rivera I-G, Ordoñez M, Presa N, Gomez-Larrauri A, Simón J, Trueba M, Gomez-Muñoz A (2015) Sphingomyelinase D/ ceramide 1-phosphate in cell survival and inflammation. Toxins (Basel) 7:1457-1466. https://doi.org/10.3390/toxins7051457

69. Arana L, Gangoiti P, Ouro A, Rivera I-G, Ordoñez M, Trueba M, Lankalapalli RS, Bittman R et al (2012) Generation of reactive oxygen species (ROS) is a key factor for stimulation of macrophage proliferation by ceramide 1-phosphate. Exp Cell Res 318: 350-360. https://doi.org/10.1016/j.yexcr.2011.11.013

70. Gangoiti P, Granado MH, Arana L, Ouro A, Gómez-Muñoz A (2008) Involvement of nitric oxide in the promotion of cell survival by ceramide 1-phosphate. FEBS Lett 582:2263-2269. https://doi.org/10.1016/j.febslet.2008.05.027

71. Pettus BJ, Bielawska A, Subramanian P, Wijesinghe DS, Maceyka M, Leslie CC, Evans JH, Freiberg J et al (2004) Ceramide 1phosphate is a direct activator of cytosolic phospholipase A2. J Biol Chem 279:11320-11326. https://doi.org/10.1074/jbc. M309262200

72. Nixon GF (2009) Sphingolipids in inflammation: pathological implications and potential therapeutic targets. Br J Pharmacol 158: 982-993. https://doi.org/10.1111/j.1476-5381.2009.00281.x

73. Simanshu DK, Kamlekar RK, Wijesinghe DS, Zou X, Zhai X, Mishra SK, Molotkovsky JG, Malinina L et al (2013) Nonvesicular trafficking by a ceramide-1-phosphate transfer protein regulates eicosanoids. Nature 500:463-467. https://doi.org/10. 1038/nature 12332

74. Granado MH, Gangoiti P, Ouro A, Arana L, González M, Trueba M, Gómez-Muñoz A (2009) Ceramide 1-phosphate (C1P) promotes cell migration involvement of a specific $\mathrm{C} 1 \mathrm{P}$ receptor. Cell Signal 21:405-412. https://doi.org/10.1016/j.cellsig.2008. 11.003

75. Crivello NA, Rosenberg IH, Dallal GE, Bielinski D, Joseph JA (2005) Age-related changes in neutral sphingomyelin-specific phospholipase $\mathrm{C}$ activity in striatum, hippocampus, and frontal cortex: implication for sensitivity to stress and inflammation. Neurochem Int 47:573-579. https://doi.org/10.1016/j.neuint. 2005.06.011

76. Katsel P, Li C, Haroutunian V (2007) Gene expression alterations in the sphingolipid metabolism pathways during progression of dementia and Alzheimer's disease: a shift toward ceramide accumulation at the earliest recognizable stages of Alzheimer's disease? Neurochem Res 32:845-856. https://doi.org/10.1007/ s11064-007-9297-x

77. He X, Huang Y, Li B, Gong C-X, Schuchman EH (2010) Deregulation of sphingolipid metabolism in Alzheimer's disease. Neurobiol Aging 31:398-408. https://doi.org/10.1016/j. neurobiolaging.2008.05.010

78. Takasugi N, Sasaki T, Suzuki K, Osawa S, Isshiki H, Hori Y, Shimada N, Higo T et al (2011) BACE1 activity is modulated by cell-associated sphingosine-1-phosphate. J Neurosci 31: 6850-6857. https://doi.org/10.1523/JNEUROSCI.6467-10.2011

79. Couttas TA, Kain N, Daniels B, Lim XY, Shepherd C, Kril J, Pickford R, Li H et al (2014) Loss of the neuroprotective factor sphingosine 1-phosphate early in Alzheimer's disease pathogenesis. Acta Neuropathol Commun 2:9. https://doi.org/10. 1186/2051-5960-2-9

80. Jové M, Naudí A, Gambini J, Borras C, Cabré R, Portero-Otín M, Viña J, Pamplona R (2017) A stress-resistant lipidomic signature confers extreme longevity to humans. J Gerontol A Biol Sci Med Sci 72:30-37. https://doi.org/10.1093/gerona/glw048

81. Varma VR, Oommen AM, Varma S, Casanova R, An Y, Andrews RM, O'Brien R, Pletnikova O et al (2018) Brain and blood metabolite signatures of pathology and progression in Alzheimer disease: a targeted metabolomics study. PLoS Med 15:e1002482. https://doi.org/10.1371/journal.pmed.1002482

82. Toledo JB, Arnold M, Kastenmüller G, Chang R, Baillie RA, Han X, Thambisetty M, Tenenbaum JD et al (2017) Metabolic network failures in Alzheimer's disease: a biochemical road map. Alzheimers Dement 13:965-984. https://doi.org/10.1016/j.jalz. 2017.01.020

83. Couttas TA, Kain N, Tran C, Chatterton Z, Kwok JB, Don AS (2018) Age-dependent changes to sphingolipid balance in the human hippocampus are gender-specific and may sensitize to neurodegeneration. J Alzheimers Dis. https://doi.org/10.3233/JAD171054

84. Babenko NA, Garkavenko VV, Storozhenko GV, Timofiychuk OA (2016) Role of acid sphingomyelinase in the age-dependent dysregulation of sphingolipids turnover in the tissues of rats. Gen Physiol Biophys 35:195-205. https://doi.org/10.4149/gpb_ 2015046

85. Fabbri E, Yang A, Simonsick EM, Chia CW, Zoli M, Haughey NJ, Mielke MM, Ferrucci L et al (2016) Circulating ceramides are inversely associated with cardiorespiratory fitness in participants aged 54-96 years from the Baltimore longitudinal study of aging. Aging Cell 15:825-831. https://doi.org/10.1111/acel.12491

86. Han X (2010) Multi-dimensional mass spectrometry-based shotgun lipidomics and the altered lipids at the mild cognitive impairment stage of Alzheimer's disease. Biochim Biophys Acta 1801: 774-783. https://doi.org/10.1016/j.bbalip.2010.01.010

87. Cutler RG, Kelly J, Storie K, Pedersen WA, Tammara A, Hatanpaa K, Troncoso JC, Mattson MP (2004) Involvement of oxidative stress-induced abnormalities in ceramide and cholesterol metabolism in brain aging and Alzheimer's disease. Proc Natl Acad Sci U S A 101:2070-2075

88. Han X, M Holtzman D, DW MK Jr, Kelley J, Morris JC (2002) Substantial sulfatide deficiency and ceramide elevation in very early Alzheimer's disease: potential role in disease pathogenesis. J Neurochem 82:809-818

89. Vozella V, Basit A, Misto A, Piomelli D (2017) Age-dependent changes in nervonic acid-containing sphingolipids in mouse hippocampus. Biochim Biophys Acta 1862:1502-1511. https://doi. org/10.1016/j.bbalip.2017.08.008

90. Šmidák R, Köfeler HC, Hoeger H, Lubec G (2017) Comprehensive identification of age-related lipidome changes in rat amygdala during normal aging. PLoS One 12:e0180675. https://doi.org/10.1371/journal.pone.0180675

91. Mielke MM, Bandaru VVR, Han D, An Y, Resnick SM, Ferrucci L, Haughey NJ (2015) Factors affecting longitudinal trajectories of plasma sphingomyelins: the Baltimore longitudinal study of aging. Aging Cell 14:112-121. https://doi.org/10.1111/acel.12275

92. Bienias K, Fiedorowicz A, Sadowska A, Prokopiuk S, Car H (2016) Regulation of sphingomyelin metabolism. Pharmacol Rep 68:570-581. https://doi.org/10.1016/j.pharep.2015.12.008

93. Nikolova-Karakashian M, Karakashian A, Rutkute K (2008) Role of neutral sphingomyelinases in aging and inflammation. Subcell Biochem 49:469-486. https://doi.org/10.1007/978-1-4020-8831-5_18

94. Labandeira-Garcia JL, Costa-Besada MA, Labandeira CM, VillarCheda B, Rodríguez-Perez AI (2017) Insulin-like growth factor-1 and Neuroinflammation. Front Aging Neurosci 9:365. https://doi. org/10.3389/fnagi.2017.00365 
95. Tripathi K, Matmati N, Zheng WJ, Hannun YA, Mohanty BK (2011) Cellular morphogenesis under stress is influenced by the sphingolipid pathway gene ISC1 and DNA integrity checkpoint genes in Saccharomyces cerevisiae. Genetics 189:533-547. https://doi.org/10.1534/genetics.111.132092

96. Aerts AM, Zabrocki P, François IEJA, Carmona-Gutierrez D, Govaert G, Mao C, Smets B, Madeo F et al (2008) Ydc1p ceramidase triggers organelle fragmentation, apoptosis and accelerated ageing in yeast. Cell Mol Life Sci 65:1933-1942. https:// doi.org/10.1007/s00018-008-8129-8

97. Jiang JC, Kirchman PA, Allen M, Jazwinski SM (2004) Suppressor analysis points to the subtle role of the LAG1 ceramide synthase gene in determining yeast longevity. Exp Gerontol 39:999-1009. https://doi.org/10.1016/j.exger.2004.03.026

98. Yang Q, Gong Z-J, Zhou Y, Yuan J-Q, Cheng J, Tian L, Li S, Lin $X-D$ et al (2010) Role of Drosophila alkaline ceramidase (Dacer) in Drosophila development and longevity. Cell Mol Life Sci 67: 1477-1490. https://doi.org/10.1007/s00018-010-0260-7

99. Cutler RG, Thompson KW, Camandola S, Mack KT, Mattson MP (2014) Sphingolipid metabolism regulates development and lifespan in Caenorhabditis elegans. Mech Ageing Dev 143-144: 9-18. https://doi.org/10.1016/j.mad.2014.11.002

100. Kim Y, Sun H (2012) ASM-3 acid sphingomyelinase functions as a positive regulator of the DAF-2/AGE-1 signaling pathway and serves as a novel anti-aging target. PLoS One 7:e45890. https:// doi.org/10.1371/journal.pone.0045890

101. Ję́śko H, Wencel P, Strosznajder RP, Strosznajder JB (2017) Sirtuins and their roles in brain aging and neurodegenerative disorders. Neurochem Res 42:876-890. https://doi.org/10.1007/ s11064-016-2110-y

102. Ortuño-Sahagún D, Pallàs M, Rojas-Mayorquín AE (2014) Oxidative stress in aging: Advances in proteomic approaches. Oxidative Med Cell Longev 2014:573208. https://doi.org/10. 1155/2014/573208

103. Martínez G, Duran-Aniotz C, Cabral-Miranda F, Vivar JP, Hetz C (2017) Endoplasmic reticulum proteostasis impairment in aging. Aging Cell 16:615-623. https://doi.org/10.1111/acel.12599

104. Syslová K, Böhmová A, Mikoška M, Kuzma M, Pelclová D, Kačer P (2014) Multimarker screening of oxidative stress in aging. Oxidative Med Cell Longev 2014:562860. https://doi.org/10. $1155 / 2014 / 562860$

105. Cutler RG, Pedersen WA, Camandola S, Rothstein JD, Mattson MP (2002) Evidence that accumulation of ceramides and cholesterol esters mediates oxidative stress-induced death of motor neurons in amyotrophic lateral sclerosis. Ann Neurol 52:448-457. https://doi.org/10.1002/ana.10312

106. Liu B, Hannun YA (1997) Inhibition of the neutral magnesiumdependent sphingomyelinase by glutathione. J Biol Chem 272: 16281-16287

107. Dbaibo GS, Pushkareva MY, Rachid RA, Alter N, Smyth MJ, Obeid LM, Hannun YA (1998) p53-dependent ceramide response to genotoxic stress. J Clin Invest 102:329-339. https://doi.org/10. 1172/JCI1180

108. MacLaren A, Black EJ, Clark W, Gillespie DAF (2004) C-Jundeficient cells undergo premature senescence as a result of spontaneous DNA damage accumulation. Mol Cell Biol 24:90069018. https://doi.org/10.1128/MCB.24.20.9006-9018.2004

109. Venable ME, Lee JY, Smyth MJ, Bielawska A, Obeid LM (1995) Role of ceramide in cellular senescence. J Biol Chem 270:3070130708

110. McNaughton M, Pitman M, Pitson SM, Pyne NJ, Pyne S (2016) Proteasomal degradation of sphingosine kinase 1 and inhibition of dihydroceramide desaturase by the sphingosine kinase inhibitors, SKi or ABC294640, induces growth arrest in androgenindependent LNCaP-AI prostate cancer cells. Oncotarget 7: 16663-16675. https://doi.org/10.18632/oncotarget.7693
111. Heffernan-Stroud LA, Helke KL, Jenkins RW, De Costa A-M, Hannun YA, Obeid LM (2012) Defining a role for sphingosine kinase 1 in p53-dependent tumors. Oncogene 31:1166-1175. https://doi.org/10.1038/onc.2011.302

112. Taha TA, Osta W, Kozhaya L, Bielawski J, Johnson KR, Gillanders WE, Dbaibo GS, Hannun YA et al (2004) Downregulation of sphingosine kinase-1 by DNA damage: dependence on proteases and p53. J Biol Chem 279:20546-20554. https://doi. org/10.1074/jbc.M401259200

113. Huwiler A, Kotelevets N, Xin C, Pastukhov O, Pfeilschifter J, Zangemeister-Wittke U (2011) Loss of sphingosine kinase-1 in carcinoma cells increases formation of reactive oxygen species and sensitivity to doxorubicin-induced DNA damage. Br J Pharmacol 162:532-543. https://doi.org/10.1111/j.1476-5381. 2010.01053.x

114. Jin Z-Q, Goetzl EJ, Karliner JS (2004) Sphingosine kinase activation mediates ischemic preconditioning in murine heart. Circulation 110:1980-1989. https://doi.org/10.1161/01.CIR. 0000143632.06471 .93

115. Min J, Mesika A, Sivaguru M, Van Veldhoven PP, Alexander H, Futerman AH, Alexander S (2007) (Dihydro)ceramide synthase 1 regulated sensitivity to cisplatin is associated with the activation of p38 mitogen-activated protein kinase and is abrogated by sphingosine kinase 1. Mol Cancer Res 5:801-812. https://doi.org/10. 1158/1541-7786.MCR-07-0100

116. van Echten-Deckert G, Zschoche A, Bär T, Schmidt RR, Raths A, Heinemann T, Sandhoff K (1997) cis-4-Methylsphingosine decreases sphingolipid biosynthesis by specifically interfering with serine palmitoyltransferase activity in primary cultured neurons. $\mathrm{J}$ Biol Chem 272:15825-15833. https://doi.org/10.1074/jbc.272.25. 15825

117. Maceyka M, Sankala H, Hait NC, Stunff HL, Liu H, Toman R, Collier C, Zhang M et al (2005) SphK1 and SphK2, sphingosine kinase isoenzymes with opposing functions in sphingolipid metabolism. J Biol Chem 280:37118-37129. https://doi.org/10.1074/ jbc.M502207200

118. Panneer Selvam S, De Palma RM, Oaks JJ, Oleinik N, Peterson YK, Stahelin RV, Skordalakes E, Ponnusamy S et al (2015) Binding of the sphingolipid S1P to hTERT stabilizes telomerase at the nuclear periphery by allosterically mimicking protein phosphorylation. Sci Signal 8:ra58. https://doi.org/10.1126/scisignal. aaa4998

119. Lu H, Yuan H, Chen S, Huang L, Xiang H, Yang G, Deng H, Zhou $\mathrm{J}$ (2012) Senescent endothelial dysfunction is attributed to the upregulation of sphingosine-1-phosphate receptor-2 in aged rats. Mol Cell Biochem 363:217-224. https://doi.org/10.1007/s11010011-1173-y

120. Zhao J, Garcia D, Gartung A, Lee M-J (2015) Sphingosine-1phosphate receptor subtype 2 signaling in endothelial senescence-associated functional impairments and inflammation. Curr Atheroscler Rep 17:504. https://doi.org/10.1007/s11883015-0504-y

121. Hsu C-K, Lee I-T, Lin C-C, Hsiao L-D, Yang C-M (2015) Sphingosine-1-phosphate mediates COX-2 expression and PGE2 /IL-6 secretion via c-Src-dependent AP-1 activation. J Cell Physiol 230:702-715. https://doi.org/10.1002/jcp. 24795

122. Osawa Y, Banno Y, Nagaki M, Brenner DA, Naiki T, Nozawa Y, Nakashima S, Moriwaki H (2001) TNF-alpha-induced sphingosine 1-phosphate inhibits apoptosis through a phosphatidylinositol 3-kinase/Akt pathway in human hepatocytes. J Immunol 167: 173-180

123. Schubert KM, Scheid MP, Duronio V (2000) Ceramide inhibits protein kinase $\mathrm{B} / \mathrm{Akt}$ by promoting dephosphorylation of serine 473. J Biol Chem 275:13330-13335 
124. Green C, Mitchell S, Speakman J (2017) Energy balance and the sphingosine-1-phosphate/ceramide axis. Aging (Albany NY) 9: 2463-2464. https://doi.org/10.18632/aging.101347

125. Hong S, Huo H, Xu J, Liao K (2004) Insulin-like growth factor-1 receptor signaling in 3T3-L1 adipocyte differentiation requires lipid rafts but not caveolae. Cell Death Differ 11:714-723. https://doi.org/10.1038/sj.cdd.4401405

126. Martin JL, Lin MZ, McGowan EM, Baxter RC (2009) Potentiation of growth factor signaling by insulin-like growth factor-binding protein-3 in breast epithelial cells requires sphingosine kinase activity. J Biol Chem 284:25542-25552. https:// doi.org/10.1074/jbc.M109.007120

127. de la Monte SM, Tong M, Nguyen V, Setshedi M, Longato L, Wands JR (2010) Ceramide-mediated insulin resistance and impairment of cognitive-motor functions. J Alzheimers Dis 21:967984. https://doi.org/10.3233/JAD-2010-091726

128. Shi L, Banerjee D, Dobierzewska A, Sathishkumar S, Karakashian AA, Giltiay NV, Nikolova-Karakashian MN (2016) Direct regulation of IGF-binding protein 1 promoter by interleukin- $1 \beta$ via an insulin- and FoxO-1-independent mechanism. Am J Physiol Endocrinol Metab 310:E612-E623. https:// doi.org/10.1152/ajpendo.00289.2015

129. Perks CM, Bowen S, Gill ZP, Newcomb PV, Holly JM (1999) Differential IGF-independent effects of insulin-like growth factor binding proteins (1-6) on apoptosis of breast epithelial cells. J Cell Biochem 75:652-664

130. Dobierzewska A, Shi L, Karakashian AA, Nikolova-Karakashian MN (2012) Interleukin $1 \beta$ regulation of FoxO1 protein content and localization: evidence for a novel ceramide-dependent mechanism. J Biol Chem 287:44749-44760. https://doi.org/10.1074/ jbc.M112.378836

131. Chan JP, Brown J, Hark B, Nolan A, Servello D, Hrobuchak H, Staab TA (2017) Loss of sphingosine kinase alters life history traits and locomotor function in Caenorhabditis elegans. Front Genet 8:132. https://doi.org/10.3389/fgene.2017.00132

132. Dibble CC, Cantley LC (2015) Regulation of mTORC1 by PI3K signaling. Trends Cell Biol 25:545-555. https://doi.org/10.1016/j. tcb.2015.06.002

133. Bernacchioni C, Cencetti F, Blescia S, Donati C, Bruni P (2012) Sphingosine kinase/sphingosine 1-phosphate axis: a new player for insulin-like growth factor-1-induced myoblast differentiation. Skelet Muscle 2:15. https://doi.org/10.1186/2044-5040-2-15

134. El-Shewy HM, Johnson KR, Lee M-H, Jaffa AA, Obeid LM, Luttrell LM (2006) Insulin-like growth factors mediate heterotrimeric $\mathrm{G}$ protein-dependent ERK1/2 activation by transactivating sphingosine 1-phosphate receptors. J Biol Chem 281:31399-31407. https://doi.org/10.1074/jbc.M605339200

135. Granata R, Trovato L, Lupia E, Sala G, Settanni F, Camussi G, Ghidoni R, Ghigo E (2007) Insulin-like growth factor binding protein-3 induces angiogenesis through IGF-I- and SphK1dependent mechanisms. J Thromb Haemost 5:835-845. https:// doi.org/10.1111/j.1538-7836.2007.02431.x

136. Igarashi J, Michel T (2001) Sphingosine 1-phosphate and isoformspecific activation of phosphoinositide 3-kinase beta. Evidence for divergence and convergence of receptor-regulated endothelial nitric-oxide synthase signaling pathways. J Biol Chem 276: 36281-36288. https://doi.org/10.1074/jbc.M105628200

137. Pyne NJ, McNaughton M, Boomkamp S, MacRitchie N, Evangelisti C, Martelli AM, Jiang H-R, Ubhi S et al (2016) Role of sphingosine 1-phosphate receptors, sphingosine kinases and sphingosine in cancer and inflammation. Adv Biol Regul 60: 151-159. https://doi.org/10.1016/j.jbior.2015.09.001

138. Banno Y, Takuwa Y, Akao Y, Okamoto H, Osawa Y, Naganawa T, Nakashima S, Suh PG et al (2001) Involvement of phospholipase $\mathrm{D}$ in sphingosine 1-phosphate-induced activation of phosphatidylinositol 3-kinase and Akt in Chinese hamster ovary cells overexpressing EDG3. J Biol Chem 276:35622-35628. https:// doi.org/10.1074/jbc.M105673200

139. Davaille J, Li L, Mallat A, Lotersztajn S (2002) Sphingosine 1phosphate triggers both apoptotic and survival signals for human hepatic myofibroblasts. J Biol Chem 277:37323-37330. https:/ doi.org/10.1074/jbc.M202798200

140. Cui H, Okamoto Y, Yoshioka K, Du W, Takuwa N, Zhang W, Asano M, Shibamoto T et al (2013) Sphingosine-1-phosphate receptor 2 protects against anaphylactic shock through suppression of endothelial nitric oxide synthase in mice. J Allergy Clin Immunol 132:1205-1214.e. https://doi.org/10.1016/j.jaci.2013. 07.026

141. Simón MV, Prado Spalm FH, Politi LE, Rotstein NP (2015) Sphingosine-1-phosphate is a crucial signal for migration of retina Müller glial cells. Invest Ophthalmol Vis Sci 56:5808-5815. https://doi.org/10.1167/iovs.14-16195

142. Takuwa Y, Okamoto Y, Yoshioka K, Takuwa N (2012) Sphingosine-1-phosphate signaling in physiology and diseases. Biofactors 38:329-337. https://doi.org/10.1002/biof.1030

143. Quint P, Ruan M, Pederson L, Kassem M, Westendorf JJ, Khosla S, Oursler MJ (2013) Sphingosine 1-phosphate (S1P) receptors 1 and 2 coordinately induce mesenchymal cell migration through S1P activation of complementary kinase pathways. J Biol Chem 288:5398-5406. https://doi.org/10.1074/jbc.M112.413583

144. Beckham TH, Cheng JC, Lu P, Shao Y, Troyer D, Lance R, Marrison ST, Norris JS et al (2013) Acid ceramidase induces sphingosine kinase 1/S1P receptor 2-mediated activation of oncogenic Akt signaling. Oncogenesis 2:e49. https://doi.org/10.1038/ oncsis.2013.14

145. Kim D-S, Kim S-Y, Kleuser B, Schäfer-Korting M, Kim KH, Park K-C (2004) Sphingosine-1-phosphate inhibits human keratinocyte proliferation via Akt/protein kinase B inactivation. Cell Signal 16: 89-95

146. Czubowicz K, Strosznajder R (2014) Ceramide in the molecular mechanisms of neuronal cell death. The role of sphingosine-1phosphate. Mol Neurobiol 50:26-37. https://doi.org/10.1007/ s12035-013-8606-4

147. Salinas M, López-Valdaliso R, Martín D, Alvarez A, Cuadrado A (2000) Inhibition of PKB/Akt1 by C2-ceramide involves activation of ceramide-activated protein phosphatase in $\mathrm{PC} 12$ cells. Mol Cell Neurosci 15:156-169. https://doi.org/10.1006/mcne.1999. 0813

148. Qin J, Berdyshev E, Poirer C, Schwartz NB, Dawson G (2012) Neutral sphingomyelinase 2 deficiency increases hyaluronan synthesis by up-regulation of Hyaluronan synthase 2 through decreased ceramide production and activation of Akt. J Biol Chem 287:13620-13632. https://doi.org/10.1074/jbc.M111.304857

149. Bourbon NA, Sandirasegarane L, Kester M (2002) Ceramideinduced inhibition of Akt is mediated through protein kinase Czeta: implications for growth arrest. J Biol Chem 277:32863292. https://doi.org/10.1074/jbc.M110541200

150. Burow ME, Weldon CB, Collins-Burow BM, Ramsey N, McKee A, Klippel A, McLachlan JA, Clejan S et al (2000) Cross-talk between phosphatidylinositol 3-kinase and sphingomyelinase pathways as a mechanism for cell survival/death decisions. J Biol Chem 275:9628-9635

151. Giussani P, Brioschi L, Bassi R, Riboni L, Viani P (2009) Phosphatidylinositol 3-kinase/AKT pathway regulates the endoplasmic reticulum to golgi traffic of ceramide in glioma cells: a link between lipid signaling pathways involved in the control of cell survival. J Biol Chem 284:5088-5096. https://doi.org/10. 1074/jbc.M808934200

152. Gómez-Muñoz A, Kong JY, Parhar K, Wang SW, Gangoiti P, González M, Eivemark S, Salh B et al (2005) Ceramide-1phosphate promotes cell survival through activation of the 
phosphatidylinositol 3-kinase/protein kinase B pathway. FEBS Lett 579:3744-3750. https://doi.org/10.1016/j.febslet.2005.05. 067

153. Gangoiti P, Granado MH, Wang SW, Kong JY, Steinbrecher UP, Gómez-Muñoz A (2008) Ceramide 1-phosphate stimulates macrophage proliferation through activation of the PI3-kinase/PKB, JNK and ERK1/2 pathways. Cell Signal 20:726-736. https://doi. org/10.1016/j.cellsig.2007.12.008

154. Cohen E, Paulsson JF, Blinder P, Burstyn-Cohen T, Du D, Estepa G, Adame A, Pham HM et al (2009) Reduced IGF-1 signaling delays age-associated proteotoxicity in mice. Cell 139:1157-1169. https://doi.org/10.1016/j.cell.2009.11.014

155. Piriz J, Muller A, Trejo JL, Torres-Aleman I (2011) IGF-I and the aging mammalian brain. Exp Gerontol 46:96-99. https://doi.org/ 10.1016/j.exger.2010.08.022

156. Ceda GP, Dall'Aglio E, Maggio M, Lauretani F, Bandinelli S, Falzoi C, Grimaldi W, Ceresini G et al (2005) Clinical implications of the reduced activity of the GH-IGF-I axis in older men. J Endocrinol Investig 28:96-100

157. Morel GR, León ML, Uriarte M, Reggiani PC, Goya RG (2017) Therapeutic potential of IGF-I on hippocampal neurogenesis and function during aging. Neurogenesis (Austin) 4:e1259709. https:// doi.org/10.1080/23262133.2016.1259709

158. Pardo J, Abba MC, Lacunza E, Ogundele OM, Paiva I, Morel GR, Outeiro TF, Goya RG (2017) IGF-I gene therapy in aging rats modulates hippocampal genes relevant to memory function. J Gerontol A Biol Sci Med Sci. https://doi.org/10.1093/gerona/ glx125

159. Lithgow GJ, Walker GA (2002) Stress resistance as a determinate of C. elegans lifespan. Mech Ageing Dev 123:765-771

160. Vermeulen CJ, Loeschcke V (2007) Longevity and the stress response in Drosophila. Exp Gerontol 42:153-159. https://doi.org/ 10.1016/j.exger.2006.09.014

161. Brown-Borg HM (2015) The somatotropic axis and longevity in mice. Am J Physiol Endocrinol Metab 309:E503-E510. https:// doi.org/10.1152/ajpendo.00262.2015

162. Selman C, Partridge L, Withers DJ (2011) Replication of extended lifespan phenotype in mice with deletion of insulin receptor substrate 1. PLoS One 6:e16144. https://doi.org/10.1371/journal. pone. 0016144

163. Alcedo J, Kenyon C (2004) Regulation of C. elegans longevity by specific gustatory and olfactory neurons. Neuron 41:45-55

164. Libert S, Zwiener J, Chu X, Vanvoorhies W, Roman G, Pletcher SD (2007) Regulation of Drosophila life span by olfaction and food-derived odors. Science 315:1133-1137. https://doi.org/10. 1126/science. 1136610

165. Kappeler L, De Magalhaes FC, Dupont J, Leneuve P, Cervera P, Périn L, Loudes C, Blaise A et al (2008) Brain IGF-1 receptors control mammalian growth and lifespan through a neuroendocrine mechanism. PLoS Biol 6:e254. https://doi.org/10.1371/journal. pbio.0060254

166. Taguchi A, Wartschow LM, White MF (2007) Brain IRS2 signaling coordinates life span and nutrient homeostasis. Science 317: 369-372. https://doi.org/10.1126/science.1142179

167. Deelen J, Uh H-W, Monajemi R, van Heemst D, Thijssen PE, Böhringer S, van den Akker EB, de Craen AJM et al (2013) Gene set analysis of GWAS data for human longevity highlights the relevance of the insulin/IGF-1 signaling and telomere maintenance pathways. Age (Dordr) 35:235-249. https://doi.org/10. 1007/s11357-011-9340-3

168. Suh Y, Atzmon G, Cho M-O, Hwang D, Liu B, Leahy DJ, Barzilai N, Cohen P (2008) Functionally significant insulin-like growth factor I receptor mutations in centenarians. Proc Natl Acad Sci U S A 105:3438-3442. https://doi.org/10.1073/pnas.0705467105

169. Bokov AF, Garg N, Ikeno Y, Thakur S, Musi N, DeFronzo RA, Zhang N, Erickson RC et al (2011) Does reduced IGF-1R signaling in Igf1 r+/- mice alter aging? PLoS One 6:e26891. https://doi.org/10.1371/journal.pone.0026891

170. Dan HC, Ebbs A, Pasparakis M, Van Dyke T, Basseres DS, Baldwin AS (2014) Akt-dependent activation of mTORC1 complex involves phosphorylation of mTOR (mammalian target of rapamycin) by IkB kinase $\alpha(\mathrm{IKK} \alpha)$. J Biol Chem 289:2522725240. https://doi.org/10.1074/jbc.M114.554881

171. Zhang J, Kim J, Alexander A, Cai S, Tripathi DN, Dere R, Tee AR, Tait-Mulder J et al (2013) A tuberous sclerosis complex signalling node at the peroxisome regulates $\mathrm{mTORC} 1$ and autophagy in response to ROS. Nat Cell Biol 15:1186-1196. https://doi.org/ $10.1038 / \mathrm{ncb} 2822$

172. Zhao Y, Hu X, Liu Y, Dong S, Wen Z, He W, Zhang S, Huang Q et al (2017) ROS signaling under metabolic stress: cross-talk between AMPK and AKT pathway. Mol Cancer 16:79. https://doi. org/10.1186/s12943-017-0648-1

173. Yuan Y, Xue X, Guo R-B, Sun X-L, Hu G (2012) Resveratrol enhances the antitumor effects of temozolomide in glioblastoma via ROS-dependent AMPK-TSC-mTOR signaling pathway. CNS Neurosci Ther 18:536-546. https://doi.org/10.1111/j.1755-5949. 2012.00319.x

174. Scott JW, Hawley SA, Green KA, Anis M, Stewart G, Scullion GA, Norman DG, Hardie DG (2004) CBS domains form energysensing modules whose binding of adenosine ligands is disrupted by disease mutations. J Clin Invest 113:274-284. https://doi.org/ 10.1172/JCI19874

175. Liu L, Cash TP, Jones RG, Keith B, Thompson CB, Simon MC (2006) Hypoxia-induced energy stress regulates mRNA translation and cell growth. Mol Cell 21:521-531. https://doi.org/10. 1016/j.molcel.2006.01.010

176. Bartolomé A, Guillén C, Benito M (2010) Role of the TSC1TSC2 complex in the integration of insulin and glucose signaling involved in pancreatic beta-cell proliferation. Endocrinology 151: 3084-3094. https://doi.org/10.1210/en.2010-0048

177. Carroll B, Maetzel D, Maddocks OD, Otten G, Ratcliff M, Smith GR, Dunlop EA, Passos JF et al (2016) Control of TSC2-Rheb signaling axis by arginine regulates mTORC1 activity. Elife 5 . https://doi.org/10.7554/eLife.11058

178. Shimobayashi M, Hall MN (2016) Multiple amino acid sensing inputs to mTORC1. Cell Res 26:7-20. https://doi.org/10.1038/cr. 2015.146

179. Maeurer C, Holland S, Pierre S, Potstada W, Scholich K (2009) Sphingosine-1-phosphate induced mTOR-activation is mediated by the E3-ubiquitin ligase PAM. Cell Signal 21:293-300. https:// doi.org/10.1016/j.cellsig.2008.10.016

180. Lavieu G, Scarlatti F, Sala G, Carpentier S, Levade T, Ghidoni R, Botti J, Codogno P (2006) Regulation of autophagy by sphingosine kinase 1 and its role in cell survival during nutrient starvation. J Biol Chem 281:8518-8527. https://doi.org/10.1074/jbc. M506182200

181. Cunningham JT, Rodgers JT, Arlow DH, Vazquez F, Mootha VK, Puigserver P (2007) mTOR controls mitochondrial oxidative function through a YY1-PGC-1alpha transcriptional complex. Nature 450:736-740. https://doi.org/10.1038/nature06322

182. Wang L, Ni Z, Liu Y, Ji S, Jin F, Jiang K, Ma J, Ren C et al (2017) Hyperactivated mTORC1 downregulation of FOXO3a/PDGFR $\alpha$ / AKT cascade restrains tuberous sclerosis complex-associated tumor development. Oncotarget 8:54858-54872. https://doi.org/10. 18632/oncotarget.18963

183. Mori S, Nada S, Kimura H, Tajima S, Takahashi Y, Kitamura A, Oneyama C, Okada M (2014) The mTOR pathway controls cell proliferation by regulating the FoxO3a transcription factor via SGK1 kinase. PLoS One 9:e88891. https://doi.org/10.1371/ journal.pone.0088891

184. Wang R, Yu Z, Sunchu B, Shoaf J, Dang I, Zhao S, Caples K, Bradley L et al (2017) Rapamycin inhibits the secretory phenotype 
of senescent cells by a Nrf2-independent mechanism. Aging Cell 16:564-574. https://doi.org/10.1111/acel.12587

185. Weichhart T (2017) mTOR as regulator of lifespan, aging, and cellular senescence: a mini-review. Gerontology 64:127-134. https://doi.org/10.1159/000484629

186. Rhee SG, Bae SH (2015) The antioxidant function of sestrins is mediated by promotion of autophagic degradation of Keap1 and Nrf2 activation and by inhibition of mTORC1. Free Radic Biol Med 88:205-211. https://doi.org/10.1016/j.freeradbiomed.2015. 06.007

187. St-Pierre J, Drori S, Uldry M, Silvaggi JM, Rhee J, Jäger S, Handschin C, Zheng K et al (2006) Suppression of reactive oxygen species and neurodegeneration by the PGC-1 transcriptional coactivators. Cell 127:397-408. https://doi.org/10.1016/j.cell. 2006.09.024

188. Lee BP, Burić I, George-Pandeth A, Flurkey K, Harrison DE, Yuan R, Peters LL, Kuchel GA et al (2017) MicroRNAs miR203-3p, miR-664-3p and miR-708-5p are associated with median strain lifespan in mice. Sci Rep 7:44620. https://doi.org/10.1038/ srep44620

189. Templeman NM, Murphy CT (2018) Regulation of reproduction and longevity by nutrient-sensing pathways. J Cell Biol 217:93106. https://doi.org/10.1083/jcb.201707168

190. Chou S-D, Prince T, Gong J, Calderwood SK (2012) mTOR is essential for the proteotoxic stress response, HSF1 activation and heat shock protein synthesis. PLoS One 7:e39679. https://doi.org/ 10.1371/journal.pone.0039679

191. Peterson TR, Sengupta SS, Harris TE, Carmack AE, Kang SA, Balderas E, Guertin DA, Madden KL et al (2011) mTOR complex 1 regulates lipin 1 localization to control the SREBP pathway. Cell 146:408-420. https://doi.org/10.1016/j.cell.2011.06.034

192. Appenzeller-Herzog C, Hall MN (2012) Bidirectional crosstalk between endoplasmic reticulum stress and mTOR signaling. Trends Cell Biol 22:274-282. https://doi.org/10.1016/j.tcb.2012. 02.006

193. Selman C, Tullet JMA, Wieser D, Irvine E, Lingard SJ, Choudhury AI, Claret M, Al-Qassab H et al (2009) Ribosomal protein S6 kinase 1 signaling regulates mammalian life span. Science 326:140-144. https://doi.org/10.1126/science.1177221

194. Selman C, Sinclair A, Pedroni SMA, Irvine EE, Michie AM, Withers DJ (2016) Evidence that hematopoietic stem cell function is preserved during aging in long-lived S6K1 mutant mice. Oncotarget 7:29937-29943. https://doi.org/10.18632/oncotarget. 8729

195. Liu J, Huang X, Withers BR, Blalock E, Liu K, Dickson RC (2013) Reducing sphingolipid synthesis orchestrates global changes to extend yeast lifespan. Aging Cell 12:833-841. https://doi.org/10.1111/acel.12107

196. Clarke CJ, Mediwala K, Jenkins RW, Sutton CA, Tholanikunnel BG, Hannun YA (2011) Neutral sphingomyelinase-2 mediates growth arrest by retinoic acid through modulation of ribosomal S6 kinase. J Biol Chem 286:21565-21576. https://doi.org/10. 1074/jbc.M110.193375

197. Rivas DA, Morris EP, Haran PH, Pasha EP, Morais Mda S, Dolnikowski GG, Phillips EM, Fielding RA (2012) Increased ceramide content and $\mathrm{NFKB}$ signaling may contribute to the attenuation of anabolic signaling after resistance exercise in aged males. J Appl Physiol 113:1727-1736. https://doi.org/10.1152/ japplphysiol.00412.2012

198. Li X, Wang M-H, Qin C, Fan W-H, Tian D-S, Liu J-L (2017) Fingolimod suppresses neuronal autophagy through the mTOR/ p70S6K pathway and alleviates ischemic brain damage in mice. PLoS One 12:e0188748. https://doi.org/10.1371/journal.pone. 0188748

199. Zhang L, Wang H, Zhu J, Ding K, Xu J (2014) FTY720 reduces migration and invasion of human glioblastoma cell lines via inhibiting the PI3K/AKT/mTOR/p70S6K signaling pathway. Tumour Biol 35:10707-10714. https://doi.org/10.1007/s13277. 014-2386-y

200. Hsieh C-T, Chuang J-H, Yang W-C, Yin Y, Lin Y (2014) Ceramide inhibits insulin-stimulated Akt phosphorylation through activation of Rheb/mTORC1/S6K signaling in skeletal muscle. Cell Signal 26:1400-1408. https://doi.org/10.1016/j. cellsig.2014.03.004

201. Guan L, Song K, Pysz MA, Curry KJ, Hizli AA, Danielpour D, Black AR, Black JD (2007) Protein kinase C-mediated down-regulation of cyclin D1 involves activation of the translational repressor 4E-BP1 via a phosphoinositide 3-kinase/Akt-independent, protein phosphatase $2 \mathrm{~A}$-dependent mechanism in intestinal epithelial cells. J Biol Chem 282:14213-14225. https://doi.org/10. 1074/jbc.M610513200

202. Kang M-J, Vasudevan D, Kang K, Kim K, Park J-E, Zhang N, Zeng X, Neubert TA et al (2017) 4E-BP is a target of the GCN2ATF4 pathway during Drosophila development and aging. J Cell Biol 216:115-129. https://doi.org/10.1083/jcb.201511073

203. Tettweiler G, Miron M, Jenkins M, Sonenberg N, Lasko PF (2005) Starvation and oxidative stress resistance in Drosophila are mediated through the eIF4E-binding protein, d4E-BP. Genes Dev 19: 1840-1843. https://doi.org/10.1101/gad.1311805

204. Le Bouffant R, Cormier P, Mulner-Lorillon O, Bellé R (2006) Hypoxia and DNA-damaging agent bleomycin both increase the cellular level of the protein 4E-BP. J Cell Biochem 99:126-132. https://doi.org/10.1002/jcb.20856

205. Sun GD, Kobayashi T, Abe M, Tada N, Adachi H, Shiota A, Totsuka Y, Hino O (2007) The endoplasmic reticulum stressinducible protein Niban regulates eIF2alpha and S6K1/4E-BP1 phosphorylation. Biochem Biophys Res Commun 360:181-187. https://doi.org/10.1016/j.bbrc.2007.06.021

206. Ryoo HD, Vasudevan D (2017) Two distinct nodes of translational inhibition in the integrated stress response. BMB Rep 50:539-545

207. Zid BM, Rogers AN, Katewa SD, Vargas MA, Kolipinski MC, Lu TA, Benzer S, Kapahi P (2009) 4E-BP extends lifespan upon dietary restriction by enhancing mitochondrial activity in Drosophila. Cell 139:149-160. https://doi.org/10.1016/j.cell. 2009.07.034

208. Alic N, Hoddinott MP, Vinti G, Partridge L (2011) Lifespan extension by increased expression of the Drosophila homologue of the IGFBP7 tumour suppressor. Aging Cell 10:137-147. https:// doi.org/10.1111/j.1474-9726.2010.00653.x

209. Tsai S, Sitzmann JM, Dastidar SG, Rodriguez AA, Vu SL, McDonald CE, Academia EC et al (2015) Muscle-specific 4EBP1 signaling activation improves metabolic parameters during aging and obesity. J Clin Invest 125:2952-2964. https://oi.org/ 10.1172/JCI77361

210. Fry CS, Drummond MJ, Glynn EL, Dickinson JM, Gundermann DM, Timmerman KL, Walker DK, Dhanani S et al (2011) Aging impairs contraction-induced human skeletal muscle mTORC1 signaling and protein synthesis. Skelet Muscle 1:11. https://doi.org/ 10.1186/2044-5040-1-11

211. Jeśso H, Strosznajder RP (2016) Sirtuins and their interactions with transcription factors and poly(ADP-ribose) polymerases. Folia Neuropathol 54:212-233

212. Antikainen H, Driscoll M, Haspel G, Dobrowolski R (2017) TORmediated regulation of metabolism in aging. Aging Cell 16:1219 1233. https://doi.org/10.1111/acel.12689

213. Chuang C-L, Lu Y-N, Wang H-C, Chang H-Y (2014) Genetic dissection reveals that Akt is the critical kinase downstream of LRRK2 to phosphorylate and inhibit FOXO1, and promotes neuron survival. Hum Mol Genet 23:5649-5658. https://doi.org/10. 1093/hmg/ddu281

214. Yun H, Park S, Kim M-J, Yang WK, Im DU, Yang KR, Hong J, Choe W et al (2014) AMP-activated protein kinase mediates the 
antioxidant effects of resveratrol through regulation of the transcription factor FoxO1. FEBS J 281:4421-4438. https://doi.org/ 10.1111/febs. 12949

215. Higuchi M, Dusting GJ, Peshavariya H, Jiang F, Hsiao ST-F, Chan EC, Liu G-S (2013) Differentiation of human adipose-derived stem cells into fat involves reactive oxygen species and Forkhead box $\mathrm{O} 1$ mediated upregulation of antioxidant enzymes. Stem Cells Dev 22:878-888. https://doi.org/10.1089/scd.2012. 0306

216. Jeong HJ, Jeong HW, Song SS, Kang JW, Seo JH, Lee YH, Lee KS, Kim DW (2011) Upregulation of peroxiredeoxin III in the hippocampus of acute immobilization stress model rats and the Foxo3a-dependent expression in PC12 cells. Cell Mol Neurobiol 31:1041-1046. https://doi.org/10.1007/s10571-011-9703-4

217. Ido Y, Duranton A, Lan F, Weikel KA, Breton L, Ruderman NB (2015) Resveratrol prevents oxidative stress-induced senescence and proliferative dysfunction by activating the AMPK-FOXO3 cascade in cultured primary human keratinocytes. PLoS One 10: e0115341. https://doi.org/10.1371/journal.pone.0115341

218. Xiong H, Wang J, Guan H, Wu J, Xu R, Wang M, Rong X, Huang $\mathrm{K}$ et al (2014) SphK1 confers resistance to apoptosis in gastric cancer cells by downregulating Bim via stimulating Akt/FoxO3a signaling. Oncol Rep 32:1369-1373. https://doi.org/10.3892/or. 2014.3391

219. Limaye V, Li X, Hahn C, Xia P, Berndt MC, Vadas MA, Gamble JR (2005) Sphingosine kinase-1 enhances endothelial cell survival through a PECAM-1-dependent activation of PI-3K/Akt and regulation of Bcl-2 family members. Blood 105:3169-3177. https:// doi.org/10.1182/blood-2004-02-0452

220. Nieuwenhuis B, Lüth A, Kleuser B (2010) Dexamethasone protects human fibroblasts from apoptosis via an S1P3-receptor subtype dependent activation of PKB/Akt and Bcl XL. Pharmacol Res 61:449-459. https://doi.org/10.1016/j.phrs.2009.12.005

221. Fabre S, Carrette F, Chen J, Lang V, Semichon M, Denoyelle C, Lazar V, Cagnard N et al (2008) FOXO1 regulates L-selectin and a network of human $\mathrm{T}$ cell homing molecules downstream of phosphatidylinositol 3-kinase. J Immunol 181:2980-2989

222. D'Ignazio L, Bandarra D, Rocha S (2016) NF-kB and HIF crosstalk in immune responses. FEBS J 283:413-424. https:// doi.org/10.1111/febs. 13578

223. Shi Z-M, Han Y-W, Han X-H, Zhang K, Chang Y-N, Hu Z-M, Qi $\mathrm{H}-\mathrm{X}$, Ting $\mathrm{C}$ et al (2016) Upstream regulators and downstream effectors of NF-kB in Alzheimer's disease. J Neurol Sci 366:127134. https://doi.org/10.1016/j.jns.2016.05.022

224. Kumar P, Raman T, Swain MM, Mishra R, Pal A (2017) Hyperglycemia-induced oxidative-nitrosative stress induces inflammation and neurodegeneration via augmented tuberous sclerosis Complex-2 (TSC-2) activation in neuronal cells. Mol Neurobiol 54:238-254. https://doi.org/10.1007/s12035-0159667-3

225. Borrás C, Gambini J, Gómez-Cabrera MC, Sastre J, Pallardó FV, Mann GE, Viña J (2005) 17beta-Oestradiol up-regulates longevity-related, antioxidant enzyme expression via the ERK1 and ERK2[MAPK]/NFkappaB cascade. Aging Cell 4:113-118. https://doi.org/10.1111/j.1474-9726.2005.00151.x

226. Lavrovsky Y, Song CS, Chatterjee B, Roy AK (2000) Agedependent increase of heme oxygenase- 1 gene expression in the liver mediated by NFkappaB. Mech Ageing Dev 114:49-60

227. Osorio FG, Soria-Valles C, Santiago-Fernández O, Freije JMP, López-Otín C (2016) NF-kB signaling as a driver of ageing. Int Rev Cell Mol Biol 326:133-174. https://doi.org/10.1016/bs. ircmb.2016.04.003

228. Kawahara TLA, Michishita E, Adler AS, Damian M, Berber E, Lin M, McCord RA, Ongaigui KCL et al (2009) SIRT6 links histone $\mathrm{H} 3$ lysine 9 deacetylation to control of NF-KB dependent gene expression and organismal lifespan. Cell 136:62-74. https:// doi.org/10.1016/j.cell.2008.10.052

229. Crescenzi E, De Palma R, Leonardi A (2012) Senescence and NFKB. Oncoimmunology 1:1594-1597. https://doi.org/10.4161/ onci.22525

230. Ham PB, Raju R (2017) Mitochondrial function in hypoxic ischemic injury and influence of aging. Prog Neurobiol 157:92-116. https://doi.org/10.1016/j.pneurobio.2016.06.006

231. Soro-Arnaiz I, Li QOY, Torres-Capelli M, Meléndez-Rodríguez F, Veiga S, Veys K, Sebastian D, Elorza A et al (2016) Role of mitochondrial complex IV in age-dependent obesity. Cell Rep 16:2991-3002. https://doi.org/10.1016/j.celrep.2016.08.041

232. Srinivasan V, Kriete A, Sacan A, Michal Jazwinski S (2010) Comparing the yeast retrograde response and NF-kB stress responses: implications for aging. Aging Cell 9:933-941. https:// doi.org/10.1111/j.1474-9726.2010.00622.x

233. Hsieh H-L, Sun C-C, Wu C-B, Wu C-Y, Tung W-H, Wang H-H, Yang C-M (2008) Sphingosine 1-phosphate induces EGFR expression via Akt/NF-kappaB and ERK/AP-1 pathways in rat vascular smooth muscle cells. J Cell Biochem 103:1732-1746. https://doi.org/10.1002/jcb. 21563

234. Theiss AL (2013) Sphingosine-1-phosphate: Driver of NFkB and STAT3 persistent activation in chronic intestinal inflammation and colitis-associated cancer. JAKSTAT 2:e24150. https://doi.org/10. $4161 /$ jkst.24150

235. Zhang W, An J, Jawadi H, Siow DL, Lee J-F, Zhao J, Gartung A, Maddipati KR et al (2013) Sphingosine-1-phosphate receptor-2 mediated NFKB activation contributes to tumor necrosis factor- $\alpha$ induced VCAM-1 and ICAM-1 expression in endothelial cells. Prostaglandins Other Lipid Mediat 106:62-71. https://doi.org/10. 1016/j.prostaglandins.2013.06.001

236. Colombo E, Di Dario M, Capitolo E, Chaabane L, Newcombe J, Martino G, Farina C (2014) Fingolimod may support neuroprotection via blockade of astrocyte nitric oxide. Ann Neurol 76:325333. https://doi.org/10.1002/ana.24217

237. van Doorn R, Lopes Pinheiro MA, Kooij G, Lakeman K, van het Hof B, van der Pol SMA, Geerts D, van Horssen J et al (2012) Sphingosine 1-phosphate receptor 5 mediates the immune quiescence of the human brain endothelial barrier. J Neuroinflammation 9:133. https://doi.org/10.1186/1742-2094-9-133

238. Boland MP, O’Neill LA (1998) Ceramide activates NFkappaB by inducing the processing of p105. J Biol Chem 273:15494-15500

239. Chang Z-Q, Lee S-Y, Kim H-J, Kim JR, Kim S-J, Hong I-K, Oh B-C, Choi C-S et al (2011) Endotoxin activates de novo sphingolipid biosynthesis via nuclear factor kappa B-mediated upregulation of Sptlc2. Prostaglandins Other Lipid Mediat 94: 44-52. https://doi.org/10.1016/j.prostaglandins.2010.12.003

240. Mechtcheriakova D, Wlachos A, Sobanov J, Kopp T, Reuschel R, Bornancin F, Cai R, Zemann B et al (2007) Sphingosine 1phosphate phosphatase 2 is induced during inflammatory responses. Cell Signal 19:748-760. https://doi.org/10.1016/j. cellsig.2006.09.004

241. Hofmeister R, Wiegmann K, Korherr C, Bernardo K, Krönke M, Falk W (1997) Activation of acid sphingomyelinase by interleukin-1 (IL-1) requires the IL-1 receptor accessory protein. J Biol Chem 272:27730-27736

242. Osborne NN, Álvarez CN, del Olmo AS (2014) Targeting mitochondrial dysfunction as in aging and glaucoma. Drug Discov Today 19:1613-1622. https://doi.org/10.1016/j.drudis.2014.05. 010

243. Jazwinski SM (2015) Mitochondria to nucleus signaling and the role of ceramide in its integration into the suite of cell quality control processes during aging. Ageing Res Rev 23:67-74. https://doi.org/10.1016/j.arr.2014.12.007

244. Jazwinski SM (2014) The retrograde response: A conserved compensatory reaction to damage from within and from without. Prog 
Mol Biol Transl Sci 127:133-154. https://doi.org/10.1016/B9780-12-394625-6.00005-2

245. Dell'agnello C, Leo S, Agostino A, Szabadkai G, Tiveron C, Zulian A, Prelle A, Roubertoux P et al (2007) Increased longevity and refractoriness to $\mathrm{Ca}(2+)$-dependent neurodegeneration in Surf1 knockout mice. Hum Mol Genet 16:431-444. https://doi. org $/ 10.1093 / \mathrm{hmg} / \mathrm{ddl} 477$

246. Jazwinski SM (2013) The retrograde response: when mitochondrial quality control is not enough. Biochim Biophys Acta 1833: 400-409. https://doi.org/10.1016/j.bbamcr.2012.02.010

247. He X, Schuchman EH (2018) Ceramide and ischemia/reperfusion injury. J Lipids 2018:3646725. https://doi.org/10.1155/2018/ 3646725

248. Patwardhan GA, Beverly LJ, Siskind LJ (2016) Sphingolipids and mitochondrial apoptosis. J Bioenerg Biomembr 48:153-168. https://doi.org/10.1007/s10863-015-9602-3

249. Kujjo LL, Acton BM, Perkins GA, Ellisman MH, D'Estaing SG, Casper RF, Jurisicova A, Perez GI (2013) Ceramide and its transport protein (CERT) contribute to deterioration of mitochondrial structure and function in aging oocytes. Mech Ageing Dev 134: 43-52. https://doi.org/10.1016/j.mad.2012.12.001

250. Yi JK, Xu R, Jeong E, Mileva I, Truman J-P, Lin C-L, Wang K, Snider J et al (2016) Aging-related elevation of sphingoid bases shortens yeast chronological life span by compromising mitochondrial function. Oncotarget 7:21124-21144. https://doi.org/10. 18632/oncotarget.8195

251. Ausman J, Abbade J, Ermini L, Farrell A, Tagliaferro A, Post M, Caniggia I (2018) Ceramide-induced BOK promotes mitochondrial fission in preeclampsia. Cell Death Dis 9:298. https://doi.org/ 10.1038/s41419-018-0360-0

252. Kwon B, Gamache T, Lee H-K, Querfurth HW (2015) Synergistic effects of $\beta$-amyloid and ceramide-induced insulin resistance on mitochondrial metabolism in neuronal cells. Biochim Biophys Acta 1852:1810-1823. https://doi.org/10.1016/j.bbadis.2015.05. 012

253. Smith ME, Tippetts TS, Brassfield ES, Tucker BJ, Ockey A, Swensen AC, Anthonymuthu TS, Washburn TD et al (2013) Mitochondrial fission mediates ceramide-induced metabolic disruption in skeletal muscle. Biochem J 456:427-439. https://doi. org/10.1042/BJ20130807

254. Rao RP, Scheffer L, Srideshikan SM, Parthibane V, KosakowskaCholody T, Masood MA, Nagashima K, Gudla P et al (2014) Ceramide transfer protein deficiency compromises organelle function and leads to senescence in primary cells. PLoS One 9:e92142. https://doi.org/10.1371/journal.pone.0092142

255. Ciarlo L, Manganelli V, Garofalo T, Matarrese P, Tinari A, Misasi R, Malorni W, Sorice M (2010) Association of fission proteins with mitochondrial raft-like domains. Cell Death Differ 17: 1047-1058. https://doi.org/10.1038/cdd.2009.208

256. Hernández-Corbacho MJ, Salama MF, Canals D, Senkal CE, Obeid LM (2017) Sphingolipids in mitochondria. Biochim Biophys Acta 1862:56-68. https://doi.org/10.1016/j.bbalip. 2016.09.019

257. Novgorodov SA, Chudakova DA, Wheeler BW, Bielawski J, Kindy MS, Obeid LM, Gudz TI (2011) Developmentally regulated ceramide synthase 6 increases mitochondrial $\mathrm{Ca} 2+$ loading capacity and promotes apoptosis. J Biol Chem 286:4644-4658. https://doi.org/10.1074/jbc.M110.164392

258. Ramírez-Camacho I, Bautista-Pérez R, Correa F, Buelna-Chontal M, Román-Anguiano NG, Medel-Franco M, Medina-Campos ON, Pedraza-Chaverri J et al (2016) Role of sphingomyelinase in mitochondrial ceramide accumulation during reperfusion. Biochim Biophys Acta 1862:1955-1963. https://doi.org/10. 1016/j.bbadis.2016.07.021

259. Novgorodov SA, Wu BX, Gudz TI, Bielawski J, Ovchinnikova TV, Hannun YA, Obeid LM (2011) Novel pathway of ceramide production in mitochondria: thioesterase and neutral ceramidase produce ceramide from sphingosine and acyl-CoA. J Biol Chem 286:25352-25362. https://doi.org/10.1074/jbc.M110.214866

260. Thomas RJ, Oleinik N, Panneer Selvam S, Vaena SG, Dany M, Nganga RN, Depalma R, Baron KD et al (2017) HPV/E7 induces chemotherapy-mediated tumor suppression by ceramidedependent mitophagy. EMBO Mol Med 9:1030-1051. https:// doi.org/10.15252/emmm.201607088

261. Shen Z, Liu C, Liu P, Zhao J, Xu W (2014) Sphingosine 1phosphate (S1P) promotes mitochondrial biogenesis in Hep G2 cells by activating peroxisome proliferator-activated receptor $\gamma$ coactivator $1 \alpha$ (PGC-1 $\alpha)$. Cell Stress Chaperones 19:541-548. https://doi.org/10.1007/s12192-013-0480-5

262. Strub GM, Paillard M, Liang J, Gomez L, Allegood JC, Hait NC, Maceyka M, Price MM et al (2011) Sphingosine-1-phosphate produced by sphingosine kinase 2 in mitochondria interacts with prohibitin 2 to regulate complex IV assembly and respiration. FASEB J 25:600-612. https://doi.org/10.1096/fj.10-167502

263. Nowatari T, Murata S, Nakayama K, Sano N, Maruyama T, Nozaki R, Ikeda N, Fukunaga K et al (2015) Sphingosine 1phosphate has anti-apoptotic effect on liver sinusoidal endothelial cells and proliferative effect on hepatocytes in a paracrine manner in human. Hepatol Res 45:1136-1145. https://doi.org/10.1111/ hepr. 12446

264. Potteck H, Nieuwenhuis B, Lüth A, van der Giet M, Kleuser B (2010) Phosphorylation of the immunomodulator FTY720 inhibits programmed cell death of fibroblasts via the S1P3 receptor subtype and Bcl-2 activation. Cell Physiol Biochem 26:67-78. https://doi.org/10.1159/000315107

265. Rutherford C, Childs S, Ohotski J, McGlynn L, Riddick M, MacFarlane S, Tasker D, Pyne S et al (2013) Regulation of cell survival by sphingosine-1-phosphate receptor S1P1 via reciprocal ERK-dependent suppression of Bim and PI-3-kinase/protein kinase C-mediated upregulation of Mcl-1. Cell Death Dis 4:e927. https://doi.org/10.1038/cddis.2013.455

266. Avery K, Avery S, Shepherd J, Heath PR, Moore H (2008) Sphingosine-1-phosphate mediates transcriptional regulation of key targets associated with survival, proliferation, and pluripotency in human embryonic stem cells. Stem Cells Dev 17:1195-1205. https://doi.org/10.1089/scd.2008.0063

267. Sawada M, Nakashima S, Banno Y, Yamakawa H, Takenaka K, Shinoda J, Nishimura Y, Sakai N et al (2000) Influence of Bax or Bcl-2 overexpression on the ceramide-dependent apoptotic pathway in glioma cells. Oncogene 19:3508-3520. https://doi.org/10. 1038/sj.onc. 1203699

268. Bektas M, Jolly PS, Müller C, Eberle J, Spiegel S, Geilen CC (2005) Sphingosine kinase activity counteracts ceramide-mediated cell death in human melanoma cells: role of Bcl-2 expression. Oncogene 24:178-118. https://doi.org/10.1038/sj.onc.1208019

269. Ueda N (2015) Ceramide-induced apoptosis in renal tubular cells: a role of mitochondria and Sphingosine-1-Phoshate. Int J Mol Sci 16:5076-5124. https://doi.org/10.3390/ijms16035076

270. Sheng R, Zhang T-T, Felice VD, Qin T, Qin Z-H, Smith CD, Sapp E, Difiglia $M$ et al (2014) Preconditioning stimuli induce autophagy via sphingosine kinase 2 in mouse cortical neurons. J Biol Chem 289:20845-20857. https://doi.org/10.1074/jbc.M114.578120

271. Ję́́ko H, Wencel PL, Lukiw WJ, Strosznajder RP (2018) Modulatory effects of Fingolimod (FTY720) on the expression of sphingolipid metabolism-related genes in an animal model of Alzheimer's disease. Mol Neurobiol. https://doi.org/10.1007/ s12035-018-1040-x

272. de la Monte SM, Tong M, Schiano I, Didsbury J (2017) Improved brain insulin/IGF signaling and reduced neuroinflammation with T3D-959 in an experimental model of sporadic Alzheimer's disease. J Alzheimers Dis 55:849-864. https://doi.org/10.3233/JAD160656 
273. George C, Gontier G, Lacube P, François J-C, Holzenberger M, Aïd S (2017) The Alzheimer's disease transcriptome mimics the neuroprotective signature of IGF-1 receptor-deficient neurons. Brain 140:2012-2027. https://doi.org/10.1093/brain/awx132

274. Xing H, Guo S, Zhang Y, Zheng Z, Wang H (2016) Upregulation of microRNA-206 enhances lipopolysaccharide-induced inflammation and release of amyloid- $\beta$ by targeting insulin-like growth factor 1 in microglia. Mol Med Rep 14:1357-1364. https://doi. org $110.3892 / \mathrm{mmr} .2016 .5369$

275. Liu H, Chu W, Gong L, Gao X, Wang W (2016) MicroRNA-26b is upregulated in a double transgenic mouse model of Alzheimer's disease and promotes the expression of amyloid- $\beta$ by targeting insulin-like growth factor 1. Mol Med Rep 13:2809-2814. https://doi.org/10.3892/mmr.2016.4860

276. Aguado-Llera D, Canelles S, Frago LM, Chowen JA, Argente J, Arilla E, Barrios V (2018) The protective effects of IGF-I against $\beta$ amyloid-related downregulation of hippocampal somatostatinergic system involve activation of Akt and protein kinase a. Neuroscience 374:104-118. https://doi.org/10.1016/j.neuroscience.2018.01.041

277. McGinley LM, Sims E, Lunn JS, Kashlan ON, Chen KS, Bruno ES, Pacut CM, Hazel T et al (2016) Human cortical neural stem cells expressing insulin-like growth factor-I: a novel cellular therapy for Alzheimer's disease. Stem Cells Transl Med 5:379-391. https://doi.org/10.5966/sctm.2015-0103

278. Malaplate-Armand C, Florent-Béchard S, Youssef I, Koziel V, Sponne I, Kriem B, Leininger-Muller B, Olivier J-L et al (2006) Soluble oligomers of amyloid-beta peptide induce neuronal apoptosis by activating a cPLA2-dependent sphingomyelinase-ceramide pathway. Neurobiol Dis 23:178-189. https://doi.org/10. 1016/j.nbd.2006.02.010

279. Jesko H, Okada T, Strosznajder RP, Nakamura S (2014) Sphingosine kinases modulate the secretion of amyloid $\beta$ precursor protein from SH-SY5Y neuroblastoma cells: the role of $\alpha$ synuclein. Folia Neuropathol 52:70-78 